\title{
Estimating the resilience of, and targets for, a transport system using expert opinion
}

Claudio Martani PhD

Research Associate, Institute for Construction and Infrastructure

Management, ETH Zürich, Zurich, Switzerland (Orcid:0000-0002-9039-0908)

(corresponding author: martani@ibi.baug.ethz.ch)

Bryan T. Adey PhD

Professor, Institute for Construction and Infrastructure Management,

ETH Zürich, Zurich, Switzerland

Ignacio Robles MSC

Engineering Consultant in Planning \& Environment, WSP Spain, Santander, Spain

Federico di Gennaro MSC

Head of Strategic Projects, Technical and International Affairs Division, Aiscat Servizi, Rome, Italy
Livia Pardi MSc

Professional Master Maintenance Engineering/Infrastructure Technical Support, Autostrade per I'Italia, Rome, Italy

Iñaki Beltran-Hernando MSC

Project Manager, Tecnalia, Basque Research and Technology Alliance, Derio, Spain

Concepcion Toribio-Diaz MSC

Researcher, Research \& Development Division, Transport Infrastructure \& Materials Area, Cemosa, Malaga, Spain

Noemi Jimenez Redondo PhD

Director, Research \& Innovation, Cemosa, Malaga, Spain

Adrián Antonio Moli Díaz MSc

Researcher, Research \& Development Division, Transport Infrastructure \& Materials Area, Cemosa, Malaga, Spain

To ensure that transport infrastructure provides acceptable levels of service with respect to extreme events, the resilience of the infrastructure needs to be estimated and targets for it need to be set. Recent work in the European research project Future Proofing Strategies for Resilient Transport Networks against Extreme Events (Foresee) has shown how this can be done in situations with a wide range of available data, time frames for the estimation and expertise. This paper provides an example of how an infrastructure manager can use the guideline to estimate the resilience of, and set resilience targets for, an example transport system in a relatively short period of time, even in the case of limited expertise in all the relevant areas and limited knowledge and information on all the basic input variables. The example is fictive but realistic. It is based on a transport system consisting of a section of the A16 highway, in Italy, where a potential landslide could discharge enough material to damage road sections and bridges. The resilience is estimated using resilience indicators with differentiated weights, and the resilience targets are set using cost-benefit analysis, to identify the indicators to be improved first.

\section{Introduction}

The functioning of society depends on the transportation of goods and persons. The infrastructure required to enable transportation is built to ensure that this can happen in specified ways - that is, built to provide the specified levels of service. As reductions in service due to natural hazards - for example, floods, earthquakes and heavy snowfalls - can have significant societal consequences, transport infrastructure managers have the mandate to minimise this risk - that is, the probability of having consequences if a natural hazard occurs multiplied by the consequences if it occurs.

In order to do so, however, it is necessary for transport infrastructure managers to, $(a)$ on the one side, have a clear idea of the service that the infrastructure is providing and an understanding of its resilience, if it is affected by natural hazards, and, $(b)$ on the other, to understand how the resilience of a network can be modified to counteract the loss of service following a hazard and to provide the specified levels of service during and following the occurrence of extreme events - that is, to set resilience targets.

A methodology to measure (i.e. to assess the importance, effect or value of (something)) the resilience of a transport infrastructure (transport infrastructure is considered to be all infrastructure for enabling travel e.g. road infrastructure and rail infrastructure or combinations of both) with respect to a defined service and set resilience targets has been proposed in the European research project Foresee - Future Proofing Strategies for Resilient Transport Networks against Extreme Events (Adey et al., 2021).

Adey et al. (2021) define service as the ability to perform an activity in a certain way. This definition can be operationalised, for example, as the ability to transport from A to B the required goods and persons within a specific amount of time without the goods being damaged and without the persons being hurt or losing their lives. They define resilience as the ability to continue to provide service if a hazard event occurs. Resilience, with this definition, is measured using each measure of service deemed relevant, in order to assess how service is being affected, and the cost of the interventions required to ensure that the infrastructure once again provides an adequate service. When considering natural hazards, resilience is therefore measured as the difference between $(a)$ the service provided by the infrastructure if no hazard event occurs and the service provided by the infrastructure if a hazard event occurs and $(b)$ the costs of intervention if no hazard event occurs and the costs of interventions if a hazard event occurs.

Adey et al. (2021) consider it possible to set targets on the maximum decrease in service/increase in intervention costs from the beginning to the end of the hazard event, the service restoration 
Infrastructure Asset Management

Volume 8 Issue 4
Estimating the resilience of, and targets

for, a transport system using expert

opinion

Martani, Adey, Robles et al. time, the shape of the restoration curve and the total reduction in service/increase in intervention costs. The targets can be set simply using the opinions of experts or using cost-benefit analysis.

This paper, meant as a companion paper to the paper by Adey et al. (2021), demonstrates how the guidelines presented methodologically by Adey et al. (2021) are to be used in practice. This is done using a fictive but realistic example transport system based on the A16 highway, in Italy, which could be exposed to hazards causing severe landslides. Given the nature of this contribution as a supplementary evidence for the paper by Adey et al. (2021), it has been considered redundant to repeat the same background and position of its companion paper. The remainder of the paper is then organised as follows. The section headed 'Situation' contains a description of the hypothetical case study situation. The section headed 'Transport system' contains the definition of the transport system. The sections headed 'Measures of service', 'Resilience indicators' and 'Resilience' contain explanations as to how service and resilience are measured. The section headed 'Targets' contains an explanation as to how the resilience indicator targets are set. The section headed 'Conclusion' contains the conclusions.

\section{Situation}

The example is developed using a section of the highway A16. The Autostrada A16 is a highway connecting Naples to Canosa, before merging with the A14 (Figure 1). The road is also known as Autostrada dei Due Mari (Motorway of the Two Seas) because it connects Naples, on the Tyrrhenian coast, with Candela, on the Adriatic coast, playing a strategic role for the connectivity of the country.

The highway passes through areas of a high-geomorphologicalhazard zone, which renders it subject to landslides of medium to severe intensity. It is considered, for the purpose of the paper, to focus on the $30.1 \mathrm{~km}$ section connecting Grottaminarda and Lacedonia. Moreover, it is assumed that the infrastructure manager has registered the hazard events that occurred in the past and has realised from the records that the potential event that is associated with the most severe consequences is a landslide of a magnitude of up to $19.3 \mathrm{kN} / \mathrm{m}$, which occurs at a frequency of $1 / 20$ years. (It is to be noticed that both the intensity and the frequency of the event here considered are invented by the authors in order to define a precise hazard, against which resilience is measured. As such, the event is fictive and does not reflect the real situation of the highway.)

In light of the importance of such an event, the infrastructure manager wishes to estimate the resilience of the transport system for the interested section with respect to a landslide of this magnitude and set resilience targets to balance optimally the cost of preventive interventions and increasing resilience. The three measures of service to be used are the travel time, safety and the socio-economic impact of people and goods not being able to travel. The infrastructure manager, aside from the many different activities carried out to provide the required service, is assumed to take care of surveillance and maintenance of the infrastructure, as well as the planning and exercise of the emergency plans in case that a hazard occurs.

According to Adey et al. (2021), for this paper, it is considered that the infrastructure manager has decided to $(a)$ estimate the resilience of the transport infrastructure using indicators with differentiated weights and (b) set resilience indicator targets with cost-benefit analysis. The decisions are motivated by the following facts.

v Given the dimension of the infrastructure and the complexity of the service considered, it would be computationally too intense to estimate the resilience using simulations.

v Using indicators, the infrastructure manager wishes to estimate the resilience with the highest possible accuracy; therefore, effort will be made to use differentiated weights - that is, an individual weight will be defined for each indicator to express the impact that each indicator has on each service considered.

- The infrastructure manager wants to set the targets based on a general idea of what might be the optimal balance between costs and benefits.

\section{Transport system}

Before taking into account the service provided by, and the resilience of, the transport infrastructure is measured and the
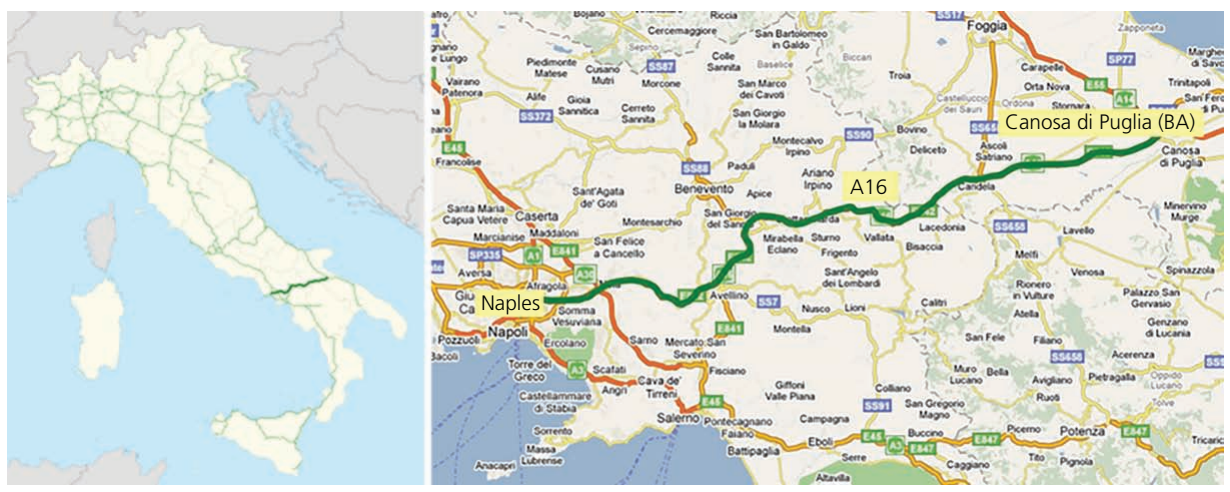

Figure 1. Diagram of location and development of the A16 highway. BA, Bari. Source: Wikipedia (2021) 
targets are set, it is necessary to define the parts of the transport system to be considered. The transport system is considered to have three main components - namely

ne infrastructure - that is, the physical assets that are required to provide the service

a the environment - that is, the physical environment in which the infrastructure is embedded that might affect the provision of service and the organisational environment in which the infrastructure management organisation is embedded that might affect the provision of service

a the organisation - that is, the organisation(s) responsible for ensuring that the infrastructure provides service.

\section{Infrastructure}

The A16 has a total length of $172300 \mathrm{~km}$, which mainly consists of double-lane road sections, which are predominately on the ground but occasionally, due to the conformation of the valley, on viaducts and in tunnels. The portion of the A16 analysed in this work is the section connecting Grottaminarda and Lacedonia. The main physical characteristics of the transport infrastructure are listed in Table 1.

The infrastructure - that is, the road sections, viaducts and tunnels - is characterised by some features that influence positively and some that influence negatively the resilience of the transport system. Some features are assumed that positively contribute to resilience include the following.

- The infrastructure is on average in very good condition as well as the slopes around it, which have been designed to comply with the slope stability design code.

- The highway is equipped with warning systems both fixed (road signs) and dynamic (digital signs) used to warn drivers of the presence of landslides, which are in relatively good condition, and of protective structures - that is, barriers to prevent landslides from hitting the road.

- There are existing ways to deviate vehicles, as well as the possibility of using another means of transport, to satisfy transport demand, in case that the traffic on the highway is interrupted - that is, as an alternative to the A16.

- In case that a landslide occurs, there are emergency measures to help evacuate people trapped on bridges and tunnels.

To influence resilience negatively, some features are assumed as follows.

Table 1. Proposed infrastructure characteristics (the data are invented by the authors and do not reflect the actual situation of the infrastructure)

$\begin{array}{lcc}\text { Input: unit } & \text { Symbol } & \text { Value } \\ \text { Length of the infrastructure: } m & L_{i} & 30100 \\ \text { Average width of the infrastructure: } m & \text { Width } & 21 \\ \text { Average height of the infrastructure: } m & \text { Height } & 0-3 \\ \text { Average condition of the infrastructure } & \text { Cs } & \text { CS2 - very good }\end{array}$

- Despite its very good condition, the infrastructure is not designed to withstand all landslide events without consequences. It is, indeed, expected that following the reference landslide, both the infrastructure and the protection barriers will be out of service and in need of rehabilitation.

- There are currently neither alert systems - that is, systems able to detect signals of landslides through environmental monitoring nor safe shutdown systems - that is, systems able to trigger an immediate blockage of road as soon as a landslide starts.

- In the most part of the chosen section, there are no possibilities to build any nearby temporary alternative route for vehicles in case that a landslide damages the highway.

\section{Environment}

The A16 covers a diversified set environmental conditions that range from a flatter landscape at the two ends and a green hilly and even mountainous - one in the central part. The soil along the highway is mainly characterised by a clay-sand component (low permeability), with rare calcareous or lithoid intercalations. In 2005, the section crossing Lacedonia - next to Avellino - was hit by a landslide that moved the road embankment at $\mathrm{km} 122.5$, forcing the closure of the road for several days. During those days, traffic was diverted in Grottaminarda.

It is assumed that a landslide of the reference magnitude has occurred in the past with a frequency of approximately $1 / 20$ years, and it is considered plausible that $(a)$ it will have a similar frequency in the future and $(b)$ that it may affect other sections of the highway. The risk on traffic and on the safety due to these events is not negligible, as there is a relatively large traffic flow on the highway. The main physical and traffic characteristics of the environment are listed in Table 2.

\section{Organisation}

The route is managed by an infrastructure manager who, among the many different activities carried out to provide the service required, takes care of surveillance and maintenance of the infrastructure. The activities performed by the infrastructure manager include conducting periodic monitoring of the condition states, executing maintenance when required, ensuring the functioning of emergency plans to react to hazard events and, when needed, preparing and managing tendering procedures for the extraordinary interventions - for example, after the event, the section has been completely rebuilt with a double-curved variant, due to the difficulty in restoring the damaged viaduct. The main physical characteristics of the organisation are listed in Table 3.

\section{Measures of service}

The service provided by the transport system is measured as the ability of road users to travel from Grottaminarda to Lacedonia on the A16 highway within a specific amount of time (travel time) and without having their property damaged or being hurt or losing their lives (safety) and the inhabitants of the area to be able to ship and have shipped goods on the highway (socio-economic activities). 
Table 2. Proposed environment characteristics (the data are invented by the authors and do not reflect the actual situation of the infrastructure)

\begin{tabular}{|c|c|c|c|}
\hline Type & Input & Symbol & Landslide [_l] \\
\hline \multirow[t]{5}{*}{ Physical } & Landslide severity: $\mathrm{m} / \mathrm{s}$ & LS & 20 \\
\hline & Landslide frequency & Lf & $1 / 20$ years \\
\hline & Soil type & Soil & Clay and sand \\
\hline & Expected amount of material to hit the infrastructure: $\mathrm{m}^{2}$ & Eam & 700 \\
\hline & Expected force with which it will hit the infrastructure - dry and saturated: $\mathrm{kN} / \mathrm{m}^{3}$ & Efm & $15.3-19.3$ \\
\hline \multirow[t]{6}{*}{ Traffic } & Speed limit (average among weather conditions): $\mathrm{km} / \mathrm{h}$ & $S_{1}$ & 120 \\
\hline & Number of people travelling per day & $P$ & 5000 \\
\hline & Number of people travelling for work in a day & $P_{\mathrm{w}}$ & 3000 \\
\hline & Number of people travelling for leisure in a day & $P_{1}$ & 2000 \\
\hline & Amount of goods travelling per day: trucks & G & 1000 \\
\hline & Vehicle transporting dangerous goods: \% of the total trucks & TRdg & 5 \\
\hline
\end{tabular}

Table 3. Proposed organisation characteristics (the data are invented by the authors and do not reflect the actual situation of the infrastructure)

Input
Annual cost of regular maintenance: $€ / m$
Days to recover in case of the reference landslide
Cost of intervention after the reference landslide: $€ / m$
Restoration plans
Average time required for the submission of tenders to repair damaged infrastructure ${ }^{\mathrm{a}}$
a The time to tender refers to the required time for selecting the tender to undergo major interventions that cannot be held by the infrastructure manager himself
(e.g. the reconstruction of a bridge). It is to be noticed that this does not refer to the time that the infrastructure is out of service, which is instead given by the
parameter $D$

Table 4. Measure of the service provided in 1 year assuming that there is no landslide

\begin{tabular}{|c|c|c|c|}
\hline Type of service & Measure & $\begin{array}{l}\text { Annual } \\
\text { estimate: } \\
\times 10^{3} €\end{array}$ & Estimated as \\
\hline Travel time $\left(S_{\mathrm{tt}}\right)$ & $\begin{array}{l}\text { Travel time for all the people } \\
\text { travelling on the viaduct }\end{array}$ & 18128 & {$\left[\left[\frac{\left(L_{i} / 1000\right)}{\left(S_{1}\right)} \times 60\right] \times\left[\left(P_{\mathrm{w}} C_{\mathrm{wt}}\right)+\left(P_{\mathrm{l}} C_{\mathrm{lt}}\right)\right] \times 365\right]$} \\
\hline Safety $\left(S_{S}\right)$ & $\begin{array}{l}\text { Cost of repairing damaged property and } \\
\text { the number of injuries and deaths due } \\
\text { to people travelling on the viaduct }\end{array}$ & 941244 & $\begin{array}{c}{\left[\left\{\left[\left(\frac{P d p_{0}}{100}\right) \times P\left(P D p_{0} \times 1000\right)\right]+\left[\left(\frac{P_{0}}{100}\right) \times P(I p \times 1000)\right]\right.\right.} \\
\left.\left.+\left[\left(\frac{P d_{0}}{100}\right) \times P(D p \times 1000)\right]\right\} \times 365\right]\end{array}$ \\
\hline $\begin{array}{l}\text { Socio-economic } \\
\text { activities }\left(S_{\text {se }}\right)\end{array}$ & $\begin{array}{l}\text { Socio-economic activity facilitated by } \\
\text { persons and goods travelling }\end{array}$ & 5475 & $\left\{\left[\left(P \times\right.\right.\right.$ Dpud $\left.\left.\left._{0} \times \mathrm{SEC}_{\mathrm{p}}\right)+\left(G \times \mathrm{Dpud}_{0} \times \mathrm{SEC}_{\mathrm{g}}\right)\right] \times 365\right\}$ \\
\hline Total & & 964848 & $\left(S_{t t}+S_{s}+S_{s c}\right)$ \\
\hline
\end{tabular}

The service provided by the infrastructure (in the absence of any landslide) is measured as shown in Table 4, where in the last column it is shown how the annual service is estimated, using inputs on the infrastructure, environment and organisation (Tables $1-4)$ and the variables affecting the service (Table 5). Table 4 should be read as follows: the measure of travel time $(€ 18127725)$ is estimated as the amount of minutes that a vehicle spends on average on the road, which is computed as the ratio of the length of the infrastructure in kilometres $\left(L_{\mathrm{i}}=30\right.$ 100/1000) to the speed limit $\left(S_{1}=120 \mathrm{~km} / \mathrm{h}\right)$ and converted into minutes (i.e. multiplied by $60 \mathrm{~min} / \mathrm{h}$ ), multiplied by the cost of that time for the users in 1 year, estimated as the sum of the average number of people travelling for work in a day $\left(P_{\mathrm{w}}=3000\right)$ for the cost of work time $\left(C_{\mathrm{wt}}=€ 0.9 / \mathrm{min}\right)$ and the average number of people travelling for leisure in a day $\left(P_{1}=2000\right)$ for the cost of leisure time $\left(C_{\mathrm{lt}}=€ 0.3 / \mathrm{min}\right)$, for 365 days. This number is used as reference number to measure deviations that are caused by the reference landslide. It is not a measure of the value of the road. The formulas for estimating the costs for safety and socioeconomic activities reported in Table 4 follow a similar logic. In total, the measures of service have a value of $€ 964.8$ million.

\section{Resilience indicators}

The infrastructure manager determined that there were 42 relevant indicators for the example transport system and defined their possible ranges of values (Tables 6-8). The indicators were selected to give an indication of the difference between the intervention costs and the service provided if no landslides occur and if the reference landslide occurs, from the start of the landslide to the time when service is again provided at the level it 
Table 5. Assumed values of variables used to measure service (the data are invented by the authors and do not reflect the actual situation of the infrastructure)

\begin{tabular}{|c|c|c|}
\hline Variable & Symbol & Value \\
\hline Daily injury probability assuming no landslide: \% & $\mathrm{Pi}_{0}$ & 0.15 \\
\hline Daily death probability assuming no landslide: \% & $\mathrm{Pd}_{0}$ & 0.01 \\
\hline $\begin{array}{l}\text { Daily property damage probability assuming no } \\
\text { landslide: \% }\end{array}$ & $P d p_{0}$ & 0.15 \\
\hline $\begin{array}{l}\text { Delay per unit (person or truck) per day assuming } \\
\text { no landslide: min/unit }\end{array}$ & Dpudo $_{0}$ & 6 \\
\hline $\begin{array}{l}\text { Property damage per person in case of no } \\
\text { accident: } \times 10^{3} \in / \text { person }\end{array}$ & $\mathrm{PDp}_{0}$ & 0.5 \\
\hline $\begin{array}{l}\text { Socio-economic costs per person - that is, the } \\
\text { cost of } 1 \text { min delay of one passenger to the } \\
\text { wither society: }(€ / \mathrm{min}) / \text { person }\end{array}$ & $S E C_{p}$ & 0.1 \\
\hline $\begin{array}{l}\text { Socio-economic costs for goods - that is, the } \\
\text { cost of } 1 \mathrm{~min} \text { delay of one truck to the wider } \\
\text { society: }(€ / \mathrm{min}) / \text { person }\end{array}$ & $\mathrm{SEC}_{\mathrm{g}}$ & 2 \\
\hline Impact of injuries per person: $\times 10^{3} € /$ person & Ip & 10 \\
\hline Impact of death per person: $\times 10^{3} \in /$ person & $\mathrm{Dp}$ & 5000 \\
\hline Cost of work time: $€ / \mathrm{min}$ & $C_{w t}$ & 0.9 \\
\hline Cost of leisure time: $€ / \min$ & $C_{l t}$ & 0.3 \\
\hline
\end{tabular}

was before the landslide. The indicators were grouped at the highest level as infrastructure, environment or organisation indicators.

Infrastructure indicators (Table 6) are considered those related to the physical man-made parts of the transport system. They consisted of condition state, protective measure and preventive measure indicators. Protective measure indicators pertained to how well the physical man-made parts of the transport system could protect the infrastructure providing the service. Preventive measure indicators pertained to how well the physical man-made parts of the transport system could withstand the reference hazard. Condition indicators pertained to how well the physical manmade parts of the transport system could provide the service it was originally designed to provide.

Environment indicators (Table 7) were those related to the physical natural parts and the non-physical man-made parts of the transport system. An example of the former is exposure to hazards. An example of the latter would be the available budget.

Organisation indicators (Table 8) are those related to non-physical man-made parts of the transport system - that is, the activities of the organisation managing the infrastructure. They consisted of pre-event and post-event activity indicators, whereas pre-event and post-event referred to the start of the landslide.

The values of all indicators were taken as averages for the entire $30 \mathrm{~km}$ road section and were thought of only in general terms (Tables 6-8). For example, the condition of the infrastructure was expressed as an average of the condition states of all objects that comprised the A16. If desired, the condition state of each category of objects (e.g. road sections, bridges and tunnels) could be treated separately. For example, if the age of the warning system (1.3.1) along the A16 highway is on average 10 years and its expected lifetime is 25 years, the indicator value is 2 . The relevancy check was used to identify if the intervention costs and each measure of service were affected by variation in the values of each indicator. For example, the presence of an emergency plan has no effect on the safety measure of service, but it has on the travel time measure of service.

\section{Resilience}

\section{Estimation}

The measures of resilience used were the cumulative differences in interventions costs and the reductions in service if each indicator had its worst and current values. This was determined by first estimating the maximum restoration intervention costs and reductions in service (Table 9) considering the transport system characteristics (Tables 1-3), and the additional assumptions listed in Table 10, and then the expected intervention costs and reductions in measures of service if each indicator had the worst possible value (Table 11). An example of the former is the maximum reduction in the travel time for work measure of service ( $€ 2.4$ million), which is estimated by multiplying the number of workers travelling per day (3000) by the average delay per person per day $(100 \mathrm{~min})$ by the cost of working time $(€ 0.9 / \mathrm{min})$ by the average number of days in which the traffic is delayed due to the restoration interventions (9). An example of the latter is that the value of the safety measure of service between the age of the warning system indicator (1.3.1) having its worst value is $€ 14.6$ million, which is $26 \%$ of the maximum expected reductions in safety if all indicators have their worst possible values - that is, $€ 54$ million. The total measure of resilience is $€ 70$ million. The age of the warning system is expected to have no effect on the restoration intervention costs or on the travel time measure of service.

\section{Measures of resilience per indicator}

The measures of resilience per indicator were computed as the expected intervention costs and reductions in the measures of service taking into consideration the value of the indicator (Tables 6-8 and 11). They are shown in Figures 2-4 for all indicators. The exact numbers are shown for a subset of these in Table 12 in terms of the maximum possible value, the actual expected value and the difference between the two. The figures show, for example, that the measures of resilience of the condition of the infrastructure (1.3.2) in terms of intervention costs and the travel time, safety and socio-economic measures of services using the worst indicator value $(0 / 5)$ - that is the max measures - are $€ 12$, $€ 3, € 54$ and $€ 1.3$ million and using the actual indicator value $(4 / 5)$ are $€ 2.4, € 0.6, € 10.8$ and $€ 0.25$ million. The former of these values mean that if the condition of the infrastructure indicator had its worst possible values, the consequences of the reference landslide would be $€ 12$ million in restoration interventions, $€ 3$ million in additional travel time, $€ 54$ million in terms of injuries and fatalities and $€ 1.3$ million for the regional economy. The latter of these values mean that in the actual situation, the 
Table 6. Proposed infrastructure resilience indicators

\begin{tabular}{|c|c|c|c|}
\hline Type & ID & Indicator & Possible values (the current values are underlined) \\
\hline \multirow[t]{7}{*}{$\begin{array}{l}\text { Protective } \\
\text { measure }\end{array}$} & 1.1 .1 & $\frac{\text { The possibility of building a temporary alternative route for }}{\text { vehicles reduces the consequences on infrastructure users }}$ & $\frac{0-\text { no alternative path }}{\text { alternative paths }} 1$ - one alternative path; 2 - multiple \\
\hline & 1.1 .2 & $\begin{array}{l}\text { The possibility of using another means to satisfy transport } \\
\text { demand reduces the consequences of an infrastructure } \\
\text { being out of service }\end{array}$ & $\begin{array}{l}0 \text { - no alternative means; } 1 \text { - one alternative means; } 2 \text { - } \\
\text { multiple alternative means }\end{array}$ \\
\hline & 1.1 .3 & $\begin{array}{l}\text { The number of possible existing alternative ways to deviate } \\
\text { vehicles reduces the consequences of an infrastructure } \\
\text { being out of service }\end{array}$ & $\begin{array}{l}0 \text { - no alternative ways; } 1 \text { - one alternative way; } 2 \text { - multiple } \\
\text { alternative ways }\end{array}$ \\
\hline & 1.1 .4 & $\begin{array}{l}\text { The presence of a warning system allows users to bypass a } \\
\text { road section in case of danger, which reduces the } \\
\text { consequences of a landslide }\end{array}$ & $\begin{array}{l}0 \text { - no warning systems; } 1 \text { - one warning system; } 2 \text { - } \\
\text { multiple warning systems }\end{array}$ \\
\hline & 1.1 .5 & $\begin{array}{l}\text { The presence of a safe shutdown system to prevent users } \\
\text { from using a damaged road section reduces the } \\
\text { consequences of a landslide }\end{array}$ & 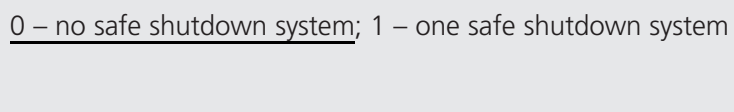 \\
\hline & 1.1 .6 & $\begin{array}{l}\text { The presence of emergency/evacuation paths allows users to } \\
\text { escape in case of danger, which reduces the consequence } \\
\text { of a landslide }\end{array}$ & $\begin{array}{l}0 \text { - no emergency path; } 1 \text { - one emergency path; } 2 \text { - } \\
\text { multiple emergency paths }\end{array}$ \\
\hline & 1.1 .7 & $\begin{array}{l}\text { The presence of special measures to help evacuate persons } \\
\text { (e.g. helicopter) allows users to escape in case of danger, } \\
\text { reducing the consequence of a landslide }\end{array}$ & $\frac{0 \text { - no extraordinary measures; } 1 \text { - one extraordinary }}{\text { measure; } 2 \text { - multiple extraordinary measures }}$ \\
\hline \multirow[t]{3}{*}{$\begin{array}{l}\text { Preventive } \\
\text { measure }\end{array}$} & 1.2 .1 & $\begin{array}{l}\text { Compliance with the current slope stability design code } \\
\text { increases the likelihood that no landslide will occur and, if } \\
\text { it does, decreases the extent of the landslide }\end{array}$ & $\begin{array}{l}0 \text { - below current regulation - for example, designed } \\
\text { according to an older design; } 1 \text { - according to current } \\
\text { regulation; } 2 \text { - above current regulation }\end{array}$ \\
\hline & 1.2 .2 & $\frac{\text { The presence of protection barriers prevents the }}{\text { infrastructure from being hit }}$ & 0 - no protection; 1 - protection \\
\hline & 1.2 .3 & $\begin{array}{l}\text { The adequacy of protection barriers (e.g. adequately } \\
\text { dimensioned and located) prevents the road section from } \\
\text { being hit by a landslide }\end{array}$ & 0 - not adequate; 1 - adequate \\
\hline \multirow[t]{7}{*}{ Condition } & 1.3 .1 & $\begin{array}{l}\text { The age/age of replacement of the warning system affects } \\
\text { the probability of accidents due to a lack of signalling in } \\
\text { case of a landslide }\end{array}$ & $\begin{array}{l}0->80 \% \text { of min. service life achieved; } 1->50 \text { and }<80 \% \\
\text { of min. service life achieved; } 2->20 \text { and }<50 \% \text { of min. } \\
\text { service life achieved; } 3-<20 \% \text { of min. service life achieved }\end{array}$ \\
\hline & 1.3 .2 & $\begin{array}{l}\text { The condition of the infrastructure providing service affects } \\
\text { the probability of the infrastructure being damaged in a } \\
\text { landslide }\end{array}$ & $\begin{array}{l}0 \text { - highly likely to collapse; } 1 \text { - no information is available; } \\
2 \text { - moderately likely to collapse; } 3 \text { - unlikely to collapse; } \\
4 \text { - very unlikely to collapse; } 5 \text { - extremely unlikely to collapse }\end{array}$ \\
\hline & 1.3 .3 & $\begin{array}{l}\text { The condition of protection barriers affects the probability } \\
\text { that they can provide the level of service for which they } \\
\text { were designed during and following the occurrence of a } \\
\text { landslide and the harder to repair them if damaged in a } \\
\text { landslide }\end{array}$ & $\begin{array}{l}0 \text { - highly likely to collapse; } 1 \text { - no information is available; } \\
2 \text { - moderately likely to collapse; } 3 \text { - unlikely to collapse; } \\
4 \text { - very unlikely to collapse; } 5 \text { - extremely unlikely to collapse }\end{array}$ \\
\hline & 1.3 .4 & $\begin{array}{l}\text { The condition of the assistance alert systems affects the } \\
\text { probability that it can provide the level of service for which } \\
\text { it was designed during and following the occurrence of a } \\
\text { landslides and the harder to repair it if damaged in a } \\
\text { landslide }\end{array}$ & $\begin{array}{l}0 \text { - highly likely to collapse under normal traffic loads; } 1 \text { - no } \\
\text { information is available; } 2 \text { - moderately likely to collapse } \\
\text { under normal traffic loads; } 3 \text { - unlikely to collapse under } \\
\text { normal traffic loads; } 4 \text {-very unlikely to collapse under } \\
\text { normal traffic loads; } 5 \text { - extremely unlikely to collapse }\end{array}$ \\
\hline & 1.3 .5 & $\frac{\text { The expected condition of infrastructure providing service }}{\text { after a landslide affects its ease of repair }}$ & $\begin{array}{l}0 \text { - collapsed, requires rebuilding; } 1 \text { - out of service, requires } \\
\frac{\text { repair/rebuilding; }}{3-\text { in service and no repairs necessary }}\end{array}$ \\
\hline & 1.3 .6 & $\begin{array}{l}\text { The expected condition of the protective barriers after a } \\
\text { landslide affects the likelihood that they will not function } \\
\text { as intended after a landslide }\end{array}$ & $\begin{array}{l}0 \text { - collapsed, requires rebuilding; } 1 \text { - out of service, requires } \\
\text { repair/rebuilding; } 2 \text { - in service but repairs are necessary; } \\
3 \text { - in service and no repairs necessary }\end{array}$ \\
\hline & 1.3 .7 & $\begin{array}{l}\text { The expected condition of assistance alert systems after a } \\
\text { landslide affects the likelihood that they will not function } \\
\text { as intended after a landslide }\end{array}$ & $\begin{array}{l}0 \text { - out of service, requires repair/rebuilding; } 1 \text { - in service } \\
\text { but repairs are necessary; } 2 \text { - in service and no repairs } \\
\text { necessary }\end{array}$ \\
\hline
\end{tabular}

consequences of the reference landslide would be $€ 2.4$ million in restoration interventions, $€ 0.6$ million in additional travel time, $€ 10.8$ million in terms of injuries and fatalities and $€ 0.25$ million for the regional economy. The maximum and actual values of the measures of resilience of the condition indicator in terms of the intervention costs and all measures of service are $€ 269.6$ and $€ 120.2$ million, respectively.

Estimating the measures of resilience for intervention costs and each measure of service in this manner provides an infrastructure 
Table 7. Proposed environment resilience indicators

\begin{tabular}{|c|c|c|c|}
\hline Type & ID & Indicator & Possible values (the current values are underlined) \\
\hline \multirow[t]{15}{*}{ Physical } & 2.1.1 & $\begin{array}{l}\text { The height of the infrastructure providing service affects } \\
\text { the consequences of an accident }\end{array}$ & $0->3 m ; 1-<3 m ; 2-$ at the same level \\
\hline & 2.1 .2 & $\frac{\text { The accessibility of the infrastructure }}{\text { and time required to restore it }}$ & $\begin{array}{l}0 \text { - accessible with telescopic crane; } 1 \text { - accessible with truck } \\
\text { mounted crane; } 2 \text {-accessible with steps; } 3 \text { - accessible } \\
\text { without equipment }\end{array}$ \\
\hline & 2.1 .3 & $\begin{array}{l}\text { The presence of persons/property below the } \\
\frac{\text { infrastructure affects the consequences if a landslide }}{\text { occurs }}\end{array}$ & $0-$ yes; $1-$ no \\
\hline & 2.1 .4 & $\begin{array}{l}\text { The extent of past damages due to landslides indicates } \\
\text { the likelihood of future damages }\end{array}$ & $\begin{array}{l}0 \text { - collapse; } 1 \text { - serious damage; } 2 \text { - minor damage; } 3 \text { - } \\
\text { aesthetic damages }\end{array}$ \\
\hline & 2.1 .5 & $\frac{\text { The hazard zone affects the likelihood of future }}{\text { landslides }}$ & 0 - high; 1 - medium; 2 - low \\
\hline & 2.1 .6 & $\begin{array}{l}\text { The frequency of past landslides affects the likelihood of } \\
\text { future landslides }\end{array}$ & $\begin{array}{l}0 \text { - location in a }<1 \text {-year landslide zone; } 1 \text { - location in a }>1 \text { - } \\
\text { and }<5 \text {-year landslide zone; } 2 \text { - location in a }>5 \text { - and }<15 \text {-year } \\
\text { landslide zone; } 3 \text { - location in a }>15 \text {-year landslide zone }\end{array}$ \\
\hline & 2.1 .7 & $\frac{\text { The severity of past landslides affects the probability of }}{\text { restoration interventions/service interruptions }}$ & $\begin{array}{l}0 \text { - collapse; } 1 \text { - serious damage; } 2 \text { - minor damage; } 3 \text { - } \\
\text { aesthetic damages }\end{array}$ \\
\hline & 2.1 .8 & $\begin{array}{l}\text { The expected frequency of future landslides affects the } \\
\text { probability of restoration interventions/service } \\
\text { interruptions }\end{array}$ & $\begin{array}{l}0 \text { - location in a }<1 \text {-year landslide zone; } 1 \text { - location in a }>1 \text { - } \\
\text { and }<5 \text {-year landslide zone; } 2 \text { - location in a }>5 \text { - and }<15 \text {-year } \\
\text { landslide zone; } 3 \text { - location in a }>15 \text {-year landslide zone }\end{array}$ \\
\hline & 2.1 .9 & $\begin{array}{l}\text { The expected severity of future landslides affects the } \\
\text { probability of restoration interventions/service } \\
\text { interruptions }\end{array}$ & $\begin{array}{l}0 \text { - strong increase; } 1 \text { - soft increase; } 2 \text { - soft decrease; } 3 \text { - } \\
\text { strong decrease }\end{array}$ \\
\hline & 2.1 .10 & $\begin{array}{l}\text { The land type affects the likelihood of future landslides } \\
\text { and the probability of restoration interventions/service } \\
\text { interruptions }\end{array}$ & 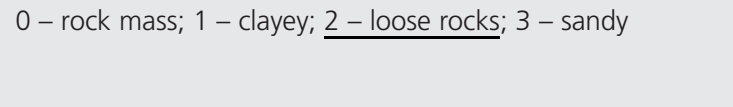 \\
\hline & 2.1 .11 & $\begin{array}{l}\text { The terrain type affects the likelihood of future landslides } \\
\text { and the probability of restoration interventions/service } \\
\text { interruptions }\end{array}$ & 0 - rugged; 1 - hilly; 2 - flat \\
\hline & 2.1 .12 & $\begin{array}{l}\text { The extent of vegetation affects the likelihood of future } \\
\text { landslides and the probability of restoration } \\
\text { interventions/service interruptions }\end{array}$ & 0 - limited; 1 - light; 2 - middle; 3 - dense \\
\hline & 2.1 .13 & $\frac{\text { The amount of traffic affects the consequences of a }}{\text { landslide }}$ & $\begin{array}{l}0->80 \% \text { of capacity; } 1->50 \text { and }<80 \% \text { of capacity; } 2 \text { - } \\
>20 \text { and }<50 \% \text { of capacity; } 3-<20 \% \text { of capacity }\end{array}$ \\
\hline & 2.1 .14 & $\frac{\text { The amount of hazardous goods traffic affects the }}{\text { consequences of an accident }}$ & $\begin{array}{l}0 \text { - frequent dangerous goods; } 1 \text { - rare dangerous goods; } \\
2 \text { - no dangerous goods }\end{array}$ \\
\hline & 2.1 .15 & $\frac{\text { The amount of flammable goods traffic affects the }}{\text { consequences of an accident }}$ & $0-$ yes; $1-$ no \\
\hline Non-physical & 2.2 .1 & $\frac{\text { The budget availability affects the likelihood that speed }}{\text { of restoration }}$ & $\begin{array}{l}0 \text { - enough for }<50 \% \text { of the interventions; } 1 \text { - enough for } \\
>50 \text { and }<100 \% \text { of the interventions; } 2 \text { - enough for } \\
>100 \% \text { of the interventions }\end{array}$ \\
\hline
\end{tabular}

manager with an idea of which of these is the most problematic and where to focus efforts on improving resilience.

It can be seen from the measures of resilience shown in this section, for example, that the safety measure of service is significantly more important than intervention costs and the travel time and socio-economic measures of service. The safety measure of service accounts for $93 \%$ of the measure of resilience for the indicators frequency of future hazards (2.1.8) and severity of future hazards (2.1.9) and $100 \%$ for the height of the infrastructure indicator (2.1.1). It can also be seen that the largest potential for improvement is by improving the value of the expected condition state of infrastructure indicator (1.3.5), which would result in an improvement of the measure of resilience by $€ 46$ million.

\section{Measures of resilience per indicator category}

The measures of resilience per indicator category are shown in Figures 5 and 6. A measure of resilience for an indicator category is the ratio between the sum of the actual values and the sum of the highest possible values of all indicators in the category multiplied by the average of the values of their individual measures of resilience. For example, the measure of resilience of indicator category 1.3, 'condition', with respect to intervention costs was given by the sum of the actual values of indicators 1.3.1 to 1.3 .7 (i.e. 15) (Table 12) divided by the sum of their highest possible values (i.e. 26) multiplied by the average of the expected intervention costs due to indicators 1.3 .1 to 1.3 .7 (i.e. $€ 2.8$ million). The measure of resilience for indicator category 1.3 with respect to intervention costs and all measures of services was $€ 1.6$ million. 
Table 8. Proposed organisation resilience indicators

\begin{tabular}{|c|c|c|c|}
\hline Type & ID & Indicator & Possible values (the current values are underlined) \\
\hline \multirow[t]{3}{*}{$\begin{array}{l}\text { Pre-event } \\
\text { activities }\end{array}$} & 3.1.1 & $\begin{array}{l}\text { The presence of a monitoring strategy raises the awareness of } \\
\text { the state of the road and is likely to increase preparedness } \\
\text { to react when necessary }\end{array}$ & $\begin{array}{l}0 \text { - no condition monitoring; } 1 \text { - periodic condition } \\
\text { monitoring; } 2 \text { - constant condition monitoring }\end{array}$ \\
\hline & 3.1 .2 & $\begin{array}{l}\text { The presence of a maintenance strategy increases the } \\
\text { likelihood that the infrastructure will be in a condition to } \\
\text { resist a landslide }\end{array}$ & $\begin{array}{l}0 \text { - no intervention strategy; } ; \frac{1-\text { only responsive }}{\text { interventions conducted; }} 2 \text { - preventive interventions } \\
\frac{\text { strategies is conducted }}{}\end{array}$ \\
\hline & 3.1 .3 & $\begin{array}{l}\text { The extent of interventions executed prior to the landslide } \\
\text { affects the likelihood that the infrastructure will be in a } \\
\text { condition to resist a landslide }\end{array}$ & $\begin{array}{l}0-<50 \% \text { of the benchmark budget; } 1->50 \text { and }<80 \% \\
\text { of the benchmark budget; } 2->80 \% \text { of the benchmark } \\
\text { budget }\end{array}$ \\
\hline \multirow[t]{6}{*}{$\begin{array}{l}\text { Post-event } \\
\text { activities }\end{array}$} & 3.2 .1 & $\begin{array}{l}\text { The presence of an emergency plan reduces the time } \\
\text { between the occurrence of a landslide and the moment that } \\
\text { a manager reacts }\end{array}$ & $\begin{array}{l}0 \text { - no plan; } 1 \text { - generic plan; } 2 \text { - operative plan (with } \\
\text { tasks, resources etc.) }\end{array}$ \\
\hline & 3.2 .2 & $\begin{array}{l}\text { The practicing of the emergency plan affects the ability of the } \\
\text { manager to use it when needed, reducing the time for } \\
\text { execution }\end{array}$ & $\begin{array}{l}0 \text { - no exercise; } 1 \text { - one exercise every }>2 \text { years; } 2 \text { - one } \\
\text { exercise every } 2 \text { years; } 3 \text { - one exercise every year; } 4- \\
\text { one exercise every } 6 \text { months }\end{array}$ \\
\hline & 3.2 .3 & $\frac{\text { The time since the last review/update of the emergency plan }}{\text { affects the likelihood that it will be fit for purpose }}$ & $0->5$ years ago; $1-<2$ years ago; $2-<5$ years ago \\
\hline & 3.2 .4 & $\begin{array}{l}\text { The expected time for tendering affects the time required to } \\
\text { restore service }\end{array}$ & $\begin{array}{l}0->1 \text { year; } 1->8 \text { months and }<1 \text { year; } 2->4 \text { and }<8 \\
\text { months; } 3-<4 \text { months }\end{array}$ \\
\hline & 3.2 .5 & $\frac{\text { The expected time for demolition of damaged infrastructure }}{\text { affects the time required to restore service }}$ & $\begin{array}{l}0->1 \text { year; } 1->8 \text { months and }<1 \text { year; } 2->4 \text { and }<8 \\
\text { months; } 3-<4 \text { months }\end{array}$ \\
\hline & 3.2 .6 & $\begin{array}{l}\text { The expected time for construction affects the time required } \\
\text { to restore service }\end{array}$ & $\begin{array}{l}0->1.5 \text { year; } 1->1 \text { and }<1.5 \text { year; } 2->6 \text { months and }<1 \\
\text { year; } 3-<6 \text { months }\end{array}$ \\
\hline
\end{tabular}

Table 9. Maximum expected restoration intervention costs and reductions in service

\begin{tabular}{|c|c|c|c|c|}
\hline \multirow{2}{*}{$\begin{array}{l}\text { Intervention costs/ } \\
\text { measure of service }\end{array}$} & \multirow{2}{*}{ Description } & \multicolumn{3}{|c|}{ Costs: $\times 10^{3} €$} \\
\hline & & Estimate & Equation & Estimate \\
\hline Intervention costs $\left(l_{i}\right)$ & The impact of executing restoration interventions & 12040 & $\left(C_{i} \times L_{i}\right)$ & 12040 \\
\hline Travel time $\left(I_{\mathrm{tt}}\right)$ & $\begin{array}{l}\text { The impact of travel condition in terms of time lost and the impact of travel } \\
\text { condition on the vehicle cost for work and leisure }\end{array}$ & $\begin{array}{r}2430 \\
540\end{array}$ & $\begin{array}{c}\left(P_{\mathrm{w}} \times \text { Dpud } \times\right. \\
\left.C_{\mathrm{wt}} \times D\right) \\
\left(P_{\mathrm{w}} \times \mathrm{Dpud} \times\right. \\
\left.C_{\mathrm{lt}} \times D\right)\end{array}$ & 2970 \\
\hline Safety $\left(I_{\mathrm{s}}\right)$ & $\begin{array}{l}\text { The impact due to the user being involved in an accident divided by } \\
\text { property damage, injury and deaths }\end{array}$ & $\begin{array}{r}3000 \\
1000 \\
50000\end{array}$ & $\begin{array}{c}{\left[\left(\frac{P p d}{100}\right) \times P D p \times P\right]} \\
{\left[\left(\frac{P p d}{p 00}\right) \times 1 p \times P\right]} \\
{\left[\left(\frac{P p d}{100}\right) \times D p p \times P\right]}\end{array}$ & 54000 \\
\hline $\begin{array}{l}\text { Socio-economic } \\
\text { activities }\left(I_{\mathrm{se}}\right)\end{array}$ & The impact of people and goods not being able to travel & $\begin{array}{l}450 \\
810\end{array}$ & $\begin{array}{l}(P \times \text { Dpud } \times D \times \\
\text { SECp }) \\
(G \times \text { Dpud } \times D \times \\
\text { SECg })\end{array}$ & 1260 \\
\hline Total & & 70270 & $\left(I_{\mathrm{i}}+I_{\mathrm{tt}}+I_{\mathrm{s}}+I_{\mathrm{se}}\right)$ & 70270 \\
\hline
\end{tabular}

Bold values are the example values discussed and explained as examples in the text from line 12 to line 30 at p. 5

Table 10. Assumptions required to estimate how service would be affected by the reference landslide (the data are invented by the authors and do not reflect the actual situation of the infrastructure)

\begin{tabular}{|c|c|c|}
\hline Variable & Symbol & Value \\
\hline $\begin{array}{l}\text { Delay per unit (person or truck) per day after the } \\
\text { reference landslide: min/unit }\end{array}$ & Dpud & 100 \\
\hline $\begin{array}{l}\text { Injury probability given occurrence of the } \\
\text { reference landslide: \% }\end{array}$ & $\mathrm{Pi}$ & 2 \\
\hline $\begin{array}{l}\text { Death probability given occurrence of the } \\
\text { reference landslide: \% }\end{array}$ & $\mathrm{Pd}$ & 0.2 \\
\hline $\begin{array}{l}\text { Property damage probability given occurrence of } \\
\text { the reference landslide: \% }\end{array}$ & Ppd & 30 \\
\hline $\begin{array}{l}\text { Property damage per person in case of accident: } \\
\times 10^{3} \in / \text { person }\end{array}$ & PDp & 2 \\
\hline
\end{tabular}

It can be seen from Figure 5 that there is the most potential to improve resilience by improving the values of the condition state of the infrastructure indicators, the pre-event activity indicators and the physical environment indicators, which have measures of resilience of $€ 9.9, € 8.3$ and $€ 5.8$ million, respectively, and that improvements to their values would have the largest impact on the safety measure of service, followed by intervention costs, with very little of the resilience related to travel time or socioeconomic impact. Figure 6 shows that the environment indicators are the largest contributor to resilience, with a value of $€ 5.6$, compared with $€ 4.34$ and $€ 4.3$ million for the organisation and infrastructure indicators. It has to be kept in mind that these values do not, of course, say anything about the ease with which 
Table 11. Expected intervention costs and reductions in measures of service if each indicator had worst possible value

\begin{tabular}{|c|c|c|c|c|c|c|}
\hline \multirow{3}{*}{ Indicator } & \multicolumn{5}{|c|}{ Costs and reductions in service: $\times 10^{3} €$} & \multirow{3}{*}{$\begin{array}{l}\text { Weight } \\
\text { total: }^{\mathrm{a}} \%\end{array}$} \\
\hline & \multirow{2}{*}{$\begin{array}{l}\text { Inter. } \\
\text { costs }\end{array}$} & \multicolumn{3}{|c|}{ Measures of service } & \multirow[b]{2}{*}{ Total } & \\
\hline & & $\begin{array}{l}\text { Travel } \\
\text { time }\end{array}$ & Safety & $\begin{array}{l}\text { Socio- } \\
\text { econ. }\end{array}$ & & \\
\hline 1.1.1 - the possibility of building a temporary alternative route for vehicles & - & 1931 & - & 819 & 2750 & 65 \\
\hline 1.1.2 - the possibility of using another means to satisfy transport demand & - & 2079 & - & 882 & 2961 & 70 \\
\hline 1.1.3 - the number of possible existing alternative ways to deviate vehicles & - & 1149 & - & 488 & 1637 & 39 \\
\hline 1.1.4 - the presence of a warning system & - & 2138 & - & 907 & 3046 & 72 \\
\hline 1.1.5 - the presence of a safe shutdown system & - & 1961 & - & 832 & 2792 & 66 \\
\hline 1.1.6 - the presence of emergency/evacuation paths & - & 1040 & - & 441 & 1481 & 35 \\
\hline 1.1.7 - the presence of special measures to help evacuate persons & - & 802 & - & 340 & 1142 & 27 \\
\hline 1.2.1 - compliance with the current slope stability design code & 8910 & 2198 & 39960 & 932 & 52000 & 74 \\
\hline 1.2 .2 - the presence of protection barriers & 10118 & 2496 & 45381 & 1059 & 59054 & 84 \\
\hline 1.2 .3 - the adequacy of protection barriers & 7465 & 1841 & 33480 & 781 & 43567 & 62 \\
\hline 1.3.1 - the age/age of replacement of the warning system & - & - & 14273 & 333 & 14606 & 26 \\
\hline 1.3.2 - the condition of the infrastructure providing service & 12040 & 2970 & 54000 & 1260 & 70270 & 100 \\
\hline 1.3.3 - the condition of protection barriers & 9391 & 2317 & 42120 & 983 & 54811 & 78 \\
\hline 1.3.4 - the condition of the assistance alert systems & 2190 & 540 & 9824 & 229 & 12783 & 18 \\
\hline 1.3.5 - the expected condition of infrastructure & 11799 & 2911 & 52920 & 1235 & 68865 & 98 \\
\hline 1.3.6 - the expected condition of the protective barriers & 7585 & 1871 & 34020 & 794 & 44270 & 63 \\
\hline 1.3.7 - the expected condition of assistance alert systems & 690 & 170 & 3095 & 72 & 4028 & 6 \\
\hline 2.1.1 - the height of the infrastructure & - & - & 14925 & - & 14925 & 28 \\
\hline 2.1.2 - the accessibility of the infrastructure & 3367 & - & - & - & 3367 & 28 \\
\hline 2.1.3 - the presence of persons/property below the infrastructure & - & - & 44280 & - & 44280 & 82 \\
\hline 2.1.4 - the extent of past damages & 6104 & - & - & - & 6104 & 51 \\
\hline 2.1.5 - the hazard zone & 9632 & 2376 & 43200 & 1008 & 56216 & 80 \\
\hline 2.1.6 - the frequency of past landslides & - & 1735 & 31552 & 736 & 34024 & 58 \\
\hline 2.1.7 - the severity of past landslides & - & 1723 & 31320 & 731 & 33773 & 58 \\
\hline 2.1.8 - the expected frequency of future landslides & - & 2228 & 40500 & 945 & 43673 & 75 \\
\hline 2.1.9 - the expected severity of future landslides & - & 2228 & 40500 & 945 & 43673 & 75 \\
\hline 2.1.10 - the land type & 4236 & - & 18998 & - & 23234 & 35 \\
\hline 2.1.11 - the terrain type & 3251 & 802 & 14580 & 340 & 18973 & 27 \\
\hline 2.1.12 - the extent of vegetation & 722 & 178 & 3240 & 76 & 4216 & 6 \\
\hline 2.1.14 - the amount of traffic & 10170 & 2509 & 45612 & 1064 & 59355 & 84 \\
\hline 2.1 .15 - the amount of hazardous goods traffic & - & - & 17280 & - & 17280 & 32 \\
\hline 2.1.16 - the amount of flammable goods traffic affects & - & - & 14252 & - & 14252 & 26 \\
\hline 2.2 .1 - the budget availability & 6863 & 1693 & 30780 & 718 & 40054 & 57 \\
\hline 3.1.1 - the presence of a monitoring strategy & 1588 & 392 & 7121 & 166 & 9267 & 13 \\
\hline 3.1.2 - the presence of a maintenance strategy & 5687 & 1403 & 25508 & 595 & 33193 & 47 \\
\hline 3.1.3 - the extent of interventions executed prior to the landslide & 9693 & 2391 & 43475 & 1014 & 56574 & 81 \\
\hline 3.2.1 - the presence of an emergency plan & - & 2020 & - & 857 & 2876 & 68 \\
\hline $\begin{array}{l}\text { 3.2.2 - the practicing of the emergency plan affects the ability of the manager to } \\
\text { use it when needed, reducing the time for execution }\end{array}$ & - & 936 & - & 397 & 1333 & 32 \\
\hline $\begin{array}{l}\text { 3.2.3 - the time since the last review/update of the emergency plan affects the } \\
\text { likelihood that it will be fit for purpose }\end{array}$ & - & 743 & 13500 & 315 & 14558 & 25 \\
\hline 3.2.4 - the expected time for tendering & 5418 & 1337 & - & 567 & 7322 & 45 \\
\hline 3.2.5 - the expected time for demolition of damaged infrastructure & 3251 & 802 & - & 340 & 4393 & 27 \\
\hline 3.2 .6 - the expected time for construction & 4575 & 1129 & - & 479 & 6183 & 38 \\
\hline
\end{tabular}

a The expected intervention costs and reductions of service due to the indicator having its current values/the maximum expected intervention costs and reductions of service multiplied by 100

the indicators can be reduced even if it is possible. This is discussed in the section headed 'Targets'.

\section{Measures of resilience for the transport system}

The measures of resilience for the whole transport system are shown in Figure 7. The measure of resilience for the intervention costs and all measures of service was $€ 4.8$ million - that is, the sum of the expected intervention cost (€0.7 million) and expected reductions in the travel time, safety and socio-economic measures of service (€0.3, €3.7 and $€ 0.13$ million) if the reference landslide occurs. The measures of resilience for the transport system were obtained with the same logic as for the indicator categories explained in the section headed 'Measures of resilience per indicator category'. For example, the safety measure of resilience was the sum of the actual values of indicators 1.1.1 to 3.2.6 (i.e. 60) divided by the sum of their highest possible values (i.e. 104) 


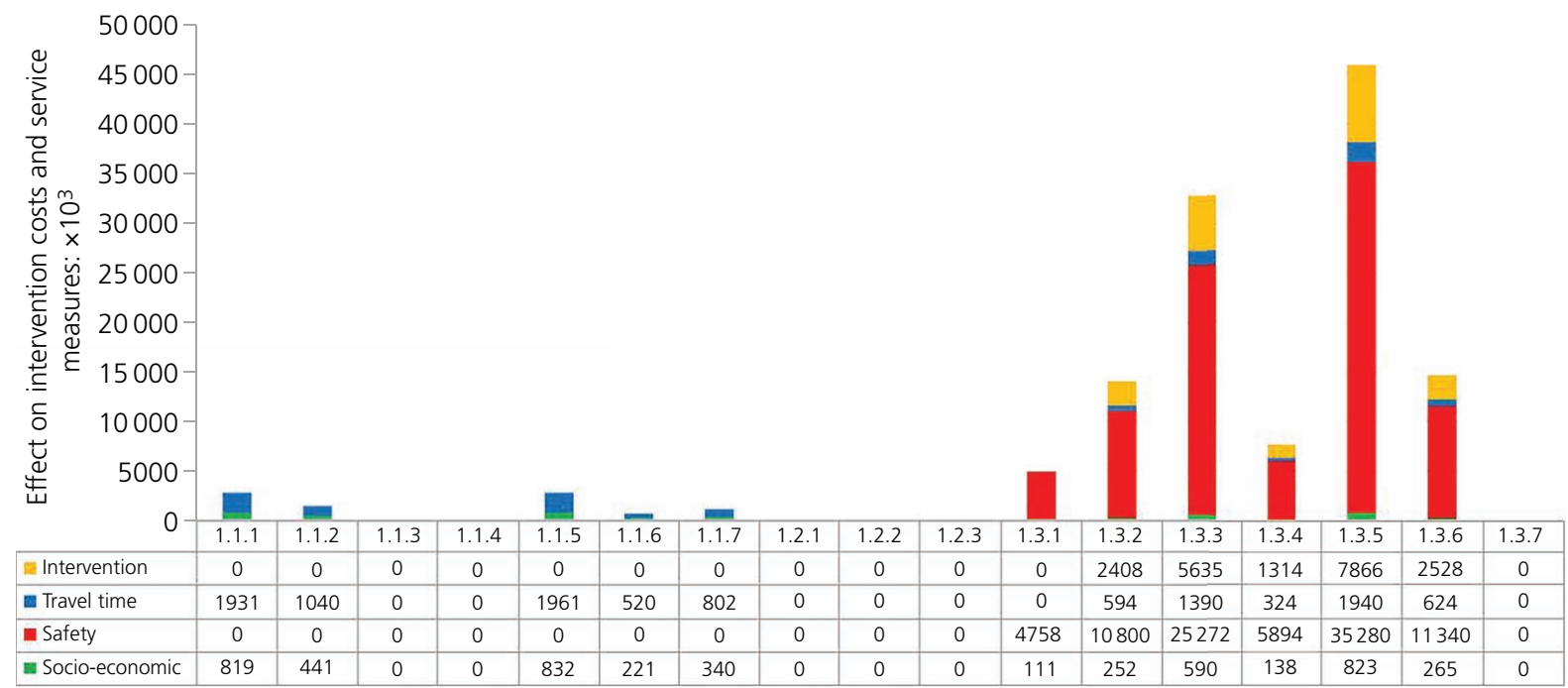

Figure 2. Infrastructure: measures of resilience for each indicator, using the actual value of all indicators, by intervention costs and each measure of service

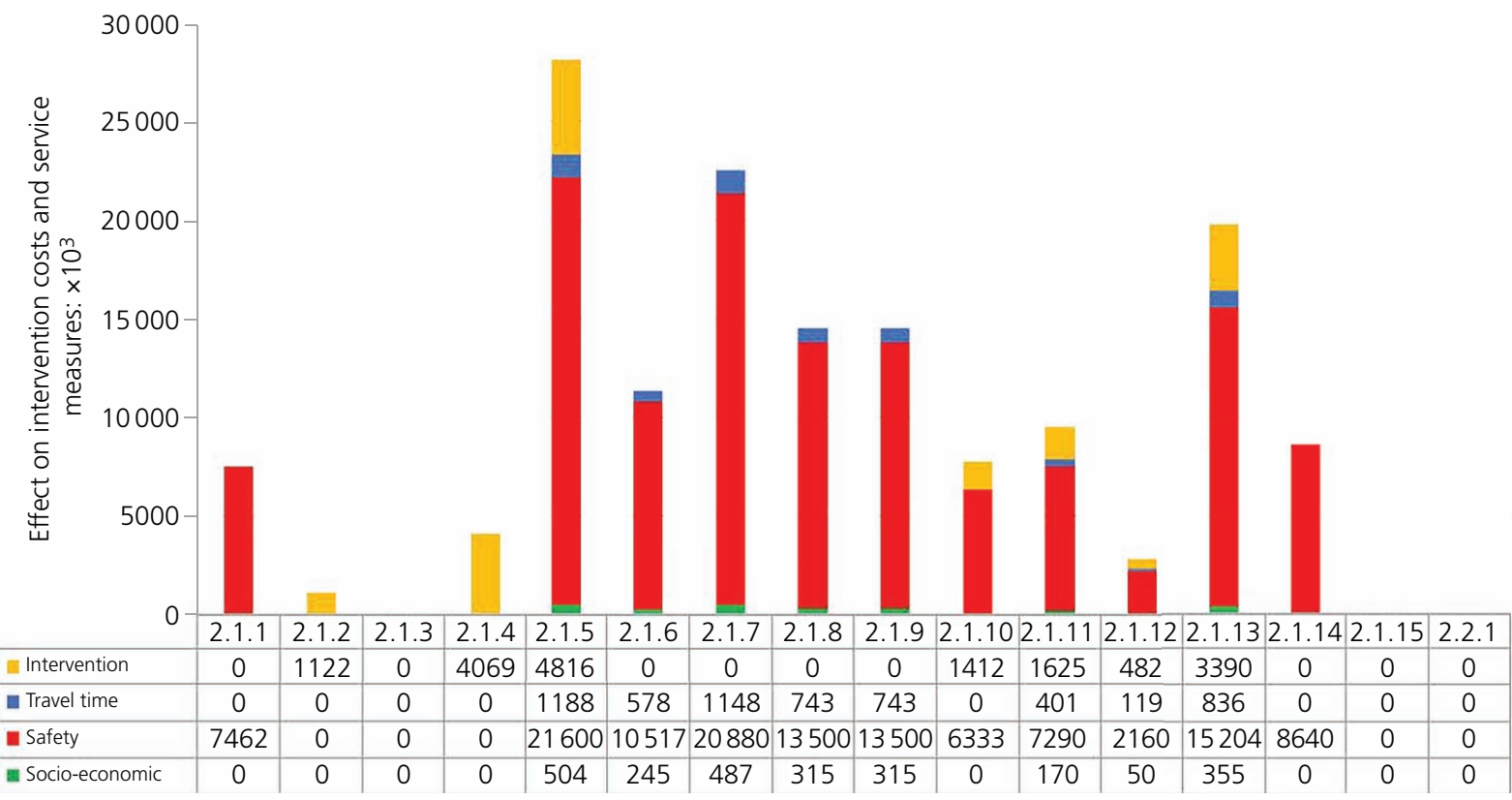

Figure 3. Environment: measures of resilience for each indicator, using the actual value of all indicators, by intervention costs and each measure of service

multiplied by the average measures of resilience per indicator (i.e. $€ 7.34$ million).

\section{Difference between measures of resilience using the} worst and actual values of indicators

The differences between the measures of resilience using the worst and actual values of indicators are shown in Figure 8 for the whole transport system and the infrastructure, environment and organisation categories using intervention costs and all measures of service. Figure 9 shows the resilience indicators for the infrastructure, environment and organisation categories using intervention costs and each measure of service. Figure 10 shows the safety measures of service for the indicator categories condition state, protection measures, preventive measures, physical and non-physical environment and pre- and post-event activities, while Figure 11 show an example of the specific expected condition state of protective barriers indicator (1.3.6). Through these figures, an infrastructure manager obtains an idea 


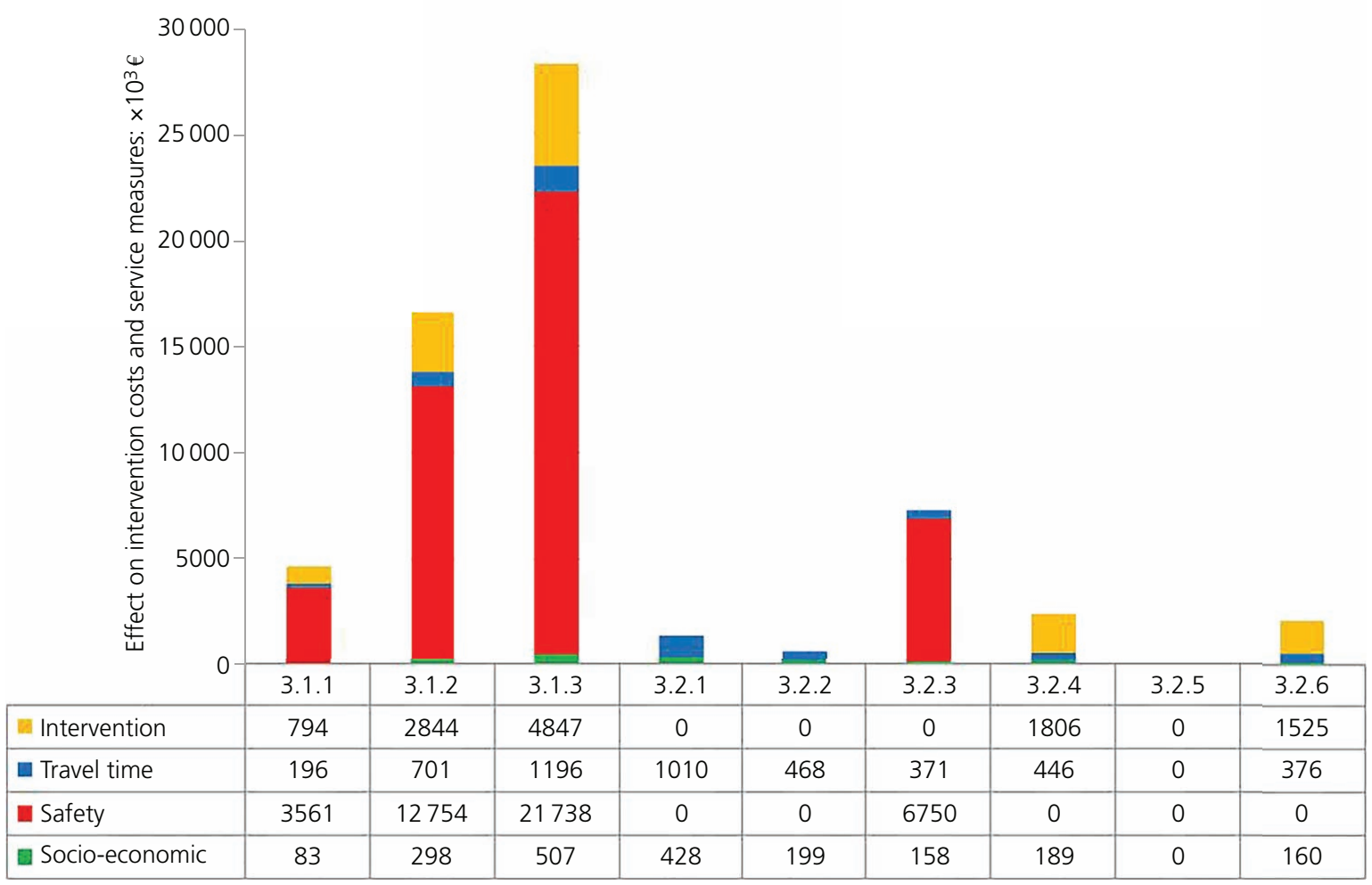

Figure 4. Organisation: measures of resilience for each indicator, using the actual value of all indicators, by intervention costs and each measure of service

Table 12. Infrastructure: measures of resilience per condition indicator (1.3)

\begin{tabular}{|c|c|c|c|c|c|c|}
\hline \multirow{3}{*}{ Indicator } & \multirow{3}{*}{ Item } & \multicolumn{5}{|c|}{ Measures of resilience: $\times 10^{3} €$} \\
\hline & & \multirow{2}{*}{ Intervention cost } & \multicolumn{3}{|c|}{ Reductions in service } & \multirow{2}{*}{ Total } \\
\hline & & & Travel time & Safety & Socio-econ. & \\
\hline \multirow[t]{3}{*}{ 1.3.1 - the age/age of replacement of the warning system } & Max & Not relevant & Not relevant & 14273 & 333 & 14606 \\
\hline & Actual & & & 4758 & 111 & 4869 \\
\hline & Difference & & & 9515 & 222 & 9737 \\
\hline \multirow[t]{3}{*}{ 1.3.2 - the condition of the infrastructure providing service } & Max & 12040 & 2970 & 54000 & 1260 & 70270 \\
\hline & Actual & 2408 & 594 & 10800 & 252 & 14054 \\
\hline & Difference & 9632 & 2376 & 43200 & 1008 & 56216 \\
\hline \multirow[t]{3}{*}{ 1.3.3 - the condition of protection barriers } & Max & 9391 & 2317 & 42120 & 983 & 54811 \\
\hline & Actual & 5635 & 1390 & 25272 & 590 & 32886 \\
\hline & Difference & 3756 & 927 & 16848 & 393 & 21924 \\
\hline \multirow[t]{3}{*}{ 1.3.4 - the condition of the assistance alert systems } & Max & 2190 & 540 & 9824 & 229 & 12783 \\
\hline & Actual & 1314 & 324 & 5894 & 138 & 7670 \\
\hline & Difference & 876 & 216 & 3929 & 92 & 5113 \\
\hline \multirow[t]{3}{*}{ 1.3.5 - the expected condition of infrastructure } & Max & 11799 & 2911 & 52920 & 1235 & 68865 \\
\hline & Actual & 7866 & 1940 & 35280 & 823 & 45910 \\
\hline & Difference & 3933 & 970 & 17640 & 412 & 22955 \\
\hline \multirow[t]{3}{*}{ 1.3.6 - the expected condition of the protective barriers } & Max & 7585 & 1871 & 34020 & 794 & 44270 \\
\hline & Actual & 2528 & 624 & 11340 & 265 & 14757 \\
\hline & Difference & 5057 & 1247 & 22680 & 529 & 29513 \\
\hline \multirow[t]{3}{*}{ 1.3.7 - the expected condition of assistance alert systems } & Max & 690 & 170 & 3095 & 72 & 4028 \\
\hline & Actual & 0 & 0 & 0 & 0 & 0 \\
\hline & Difference & 690 & 170 & 3095 & 72 & 4028 \\
\hline \multirow[t]{3}{*}{ Total } & Max & 43696 & 10779 & 210252 & 4906 & 269633 \\
\hline & Actual & 19751 & 4872 & 93344 & 2178 & 120146 \\
\hline & Difference & 23945 & 5907 & 116908 & 2728 & 149487 \\
\hline
\end{tabular}

Bold text is the example indicator used to illustrate the computations for measuring the uncertainty in the text at p. 5 from line 37 


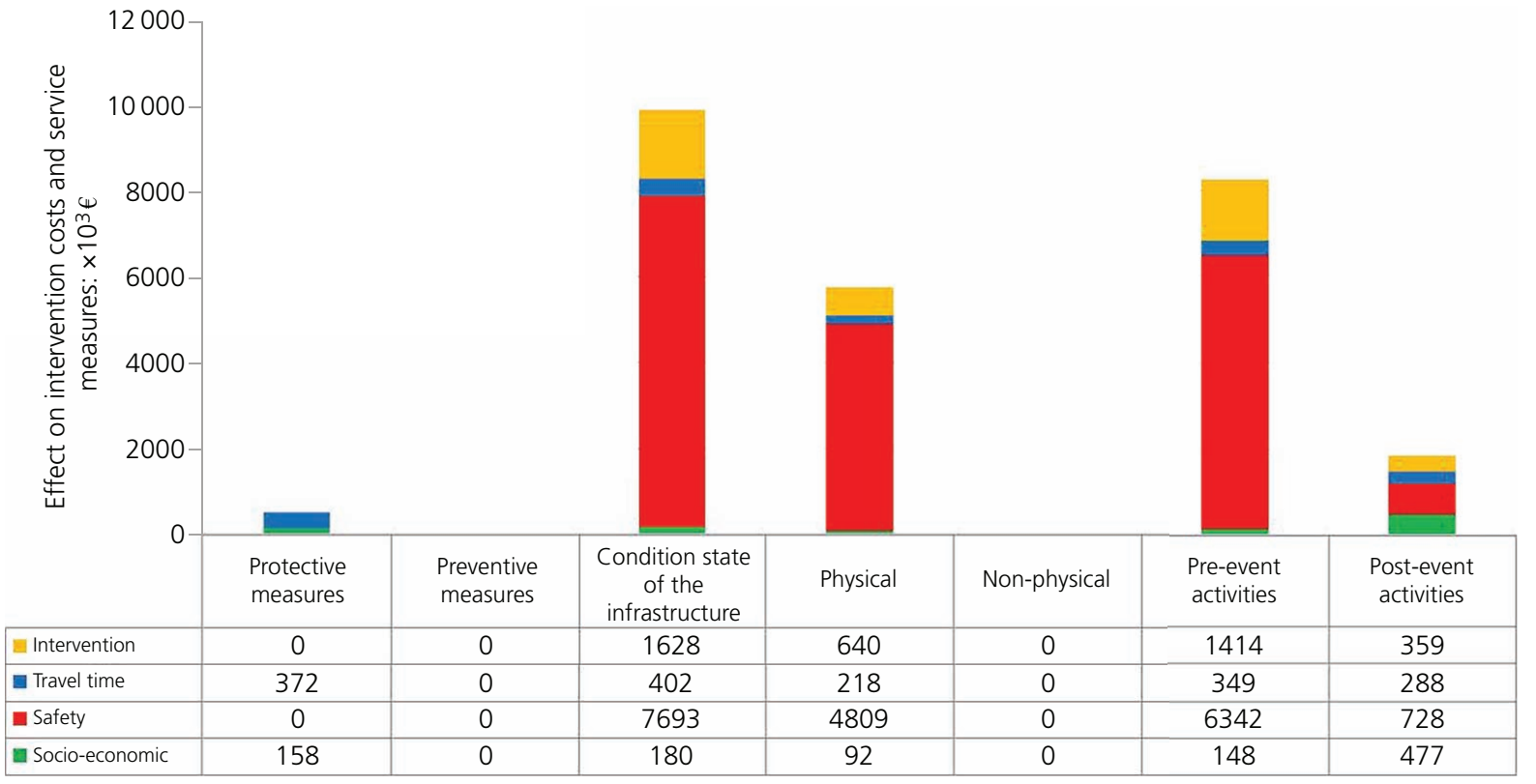

Figure 5. Measures of resilience for the condition state, protection measures, preventive measures, physical and non-physical environment and pre- and post-event activity indicator categories

of how much better and how much worse resilience can be. For example, although the measure of resilience of the transport system is $€ 4.8$ million (Figure 8 ), which is arguably a high number, it is less than half of what it could be - that is, €14.4 million. Although alone this might not be even much information, it would be very useful if it is used to track resilience over time. It can also be seen quickly where little or no additional improvements in resilience can be achieved. For example, the protective measures indicator category (Figure 10) is not relevant with respect to safety so if safety is of concern, no improvements

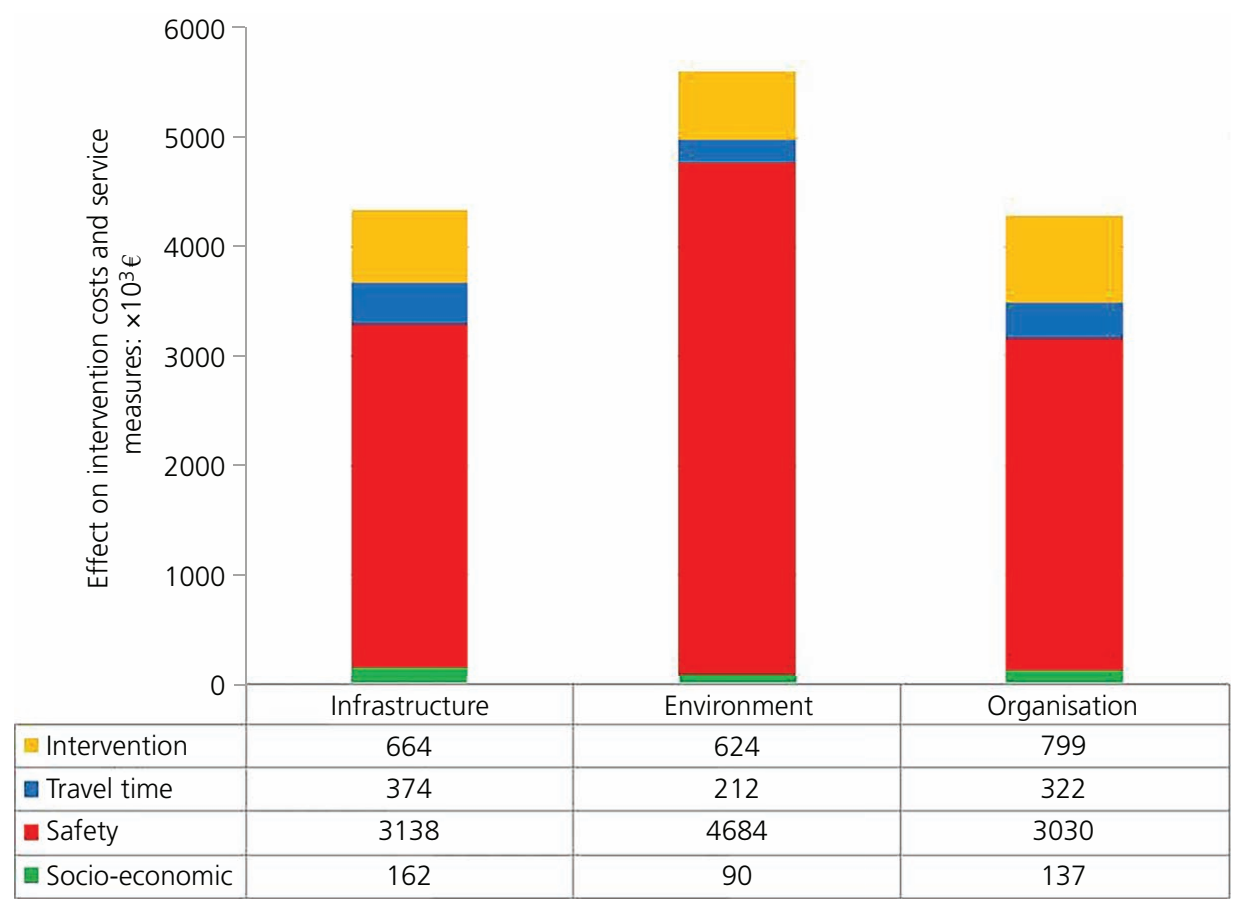

Figure 6. Measures of resilience for the infrastructure, environment and organisation indicator categories 
Estimating the resilience of, and targets

for, a transport system using expert

opinion

Martani, Adey, Robles et al.

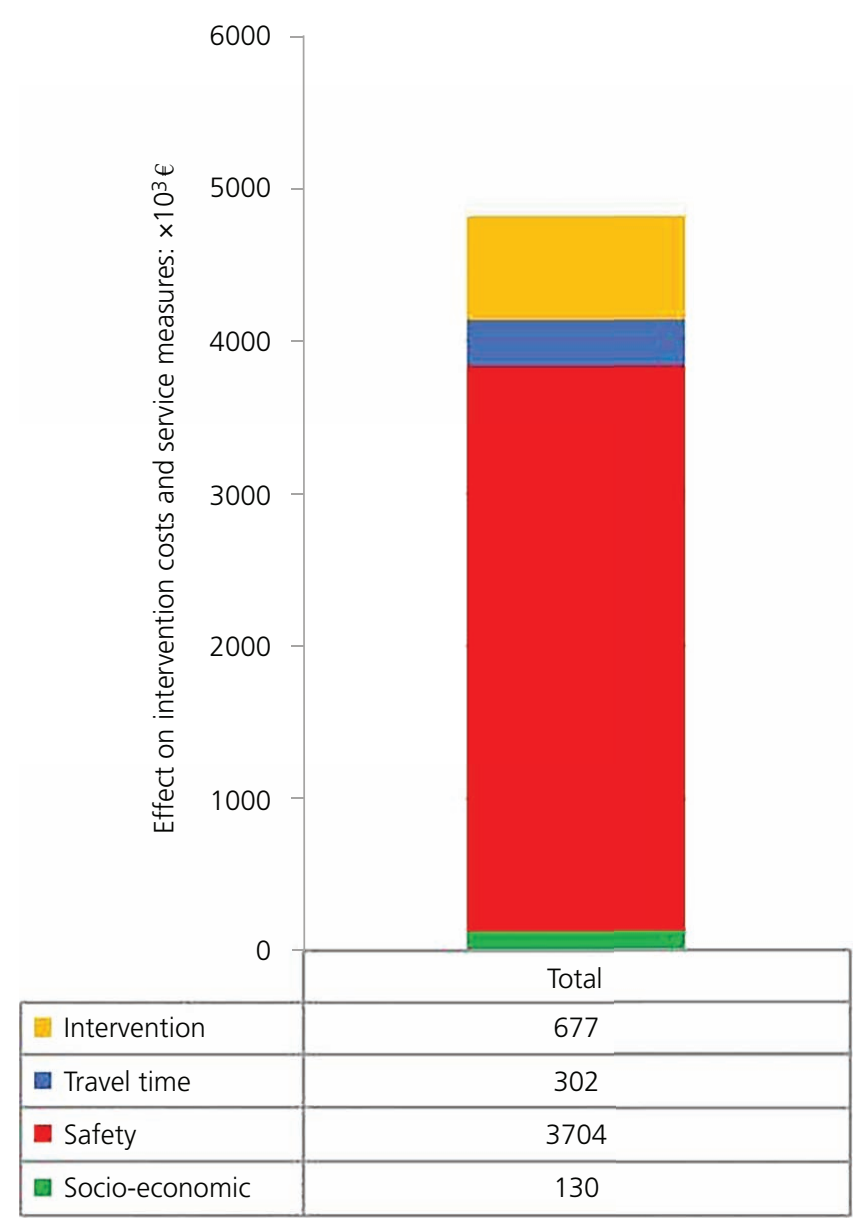

Figure 7. Measures of resilience for the transport system are possible through the improvements of these measures. Moreover, improvements are not possible by improving the values of the preventive measures indicators, as they all already have their best values. In contrast, improvements are possible by improving the values of the indicators, such as the expected condition state of protective barriers indicator (Figure 12).

\section{Summary}

The resilience of the transport system is relatively good ( $€ 4.8$ million compared with the maximum possible value of $€ 14.4$ million (only $33.3 \%)$ ). The greatest contributor to the $€ 4.8$ million is the environment, followed by the organisation and the infrastructure, with measures of resilience of $€ 5.6, € 4.34$ and $€ 4.3$ million. This is mainly due to the fact that, for the example, the infrastructure is assumed to be out of service and the protection barriers moderately likely collapsed following the occurrence of a reference landslide. Although both the infrastructure and the barriers are designed to withstand reference landslides, they are still expected to be severely damaged if the landslides occur, and consequently, significant repair or even a replacement is likely to be required.

These facts can be clearly seen by looking closely at the indicator categories and indicators themselves. Looking at the indicator categories, it can be seen that the greatest contributors in terms of indicator categories are the infrastructure condition indicators, the pre-event activity indicators and the physical environment indicators, with measures of resilience of $€ 9.9, € 8.3$ and $€ 5.8$ million, respectively. Looking at the specific indicators, the greatest contributors are the expected condition of infrastructure (1.3.5), €46 million; the condition of protection barriers (1.3.3), $€ 33$ million; the extent of interventions executed prior to the landslide (3.1.3), €28.3 million; and the hazard zone (2.1.5), €28.1 million.

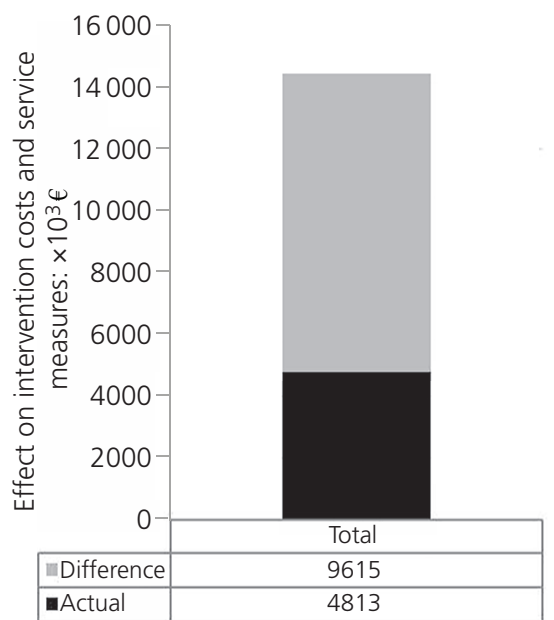

(a)

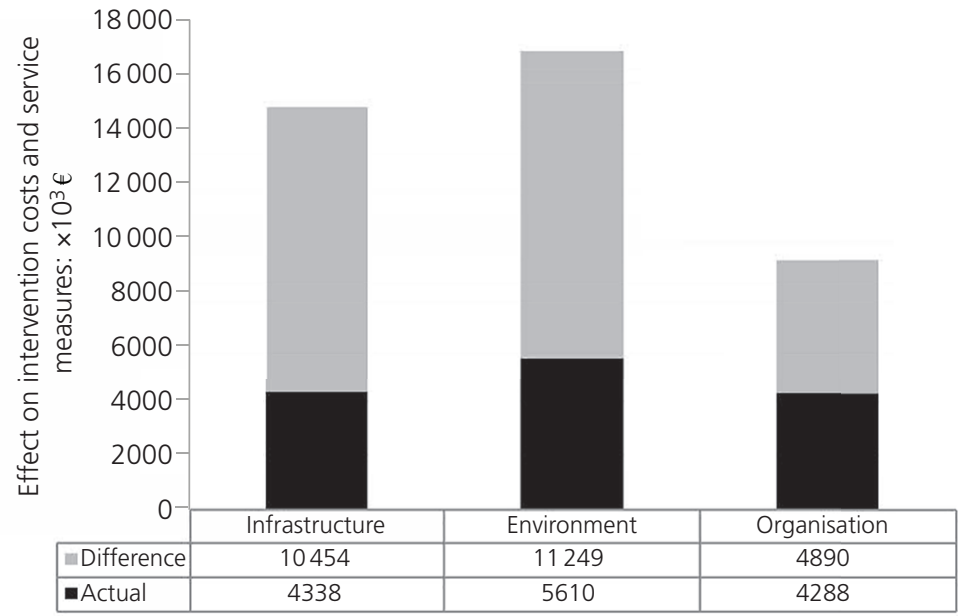

(b)

Figure 8. Difference between measures of resilience for (a) the transport system and (b) the infrastructure, environment and organisation categories 


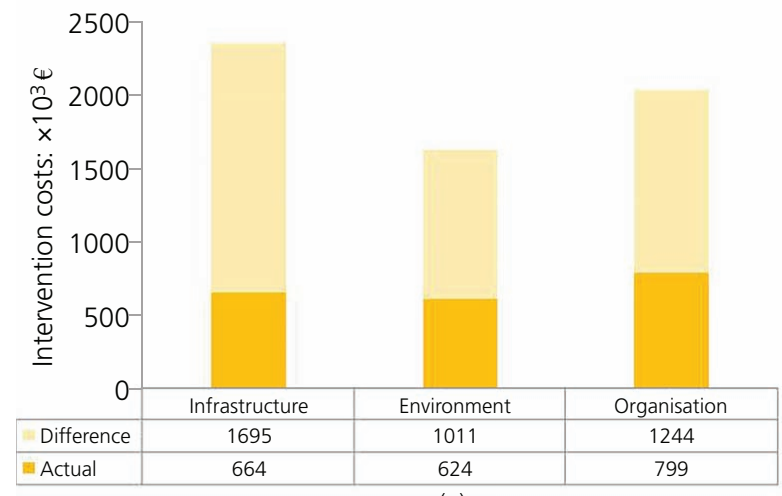

(a)

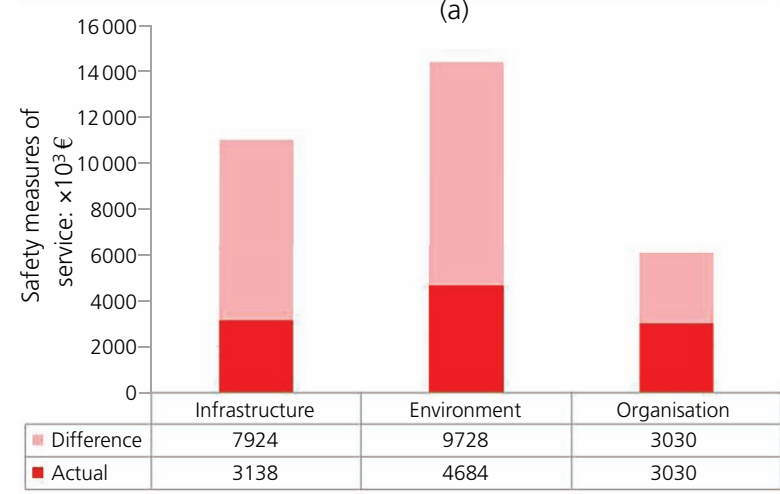

(c)

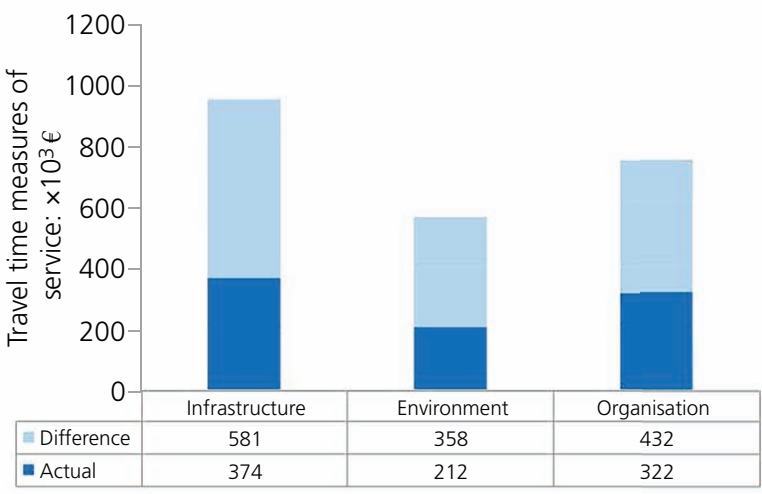

(b)

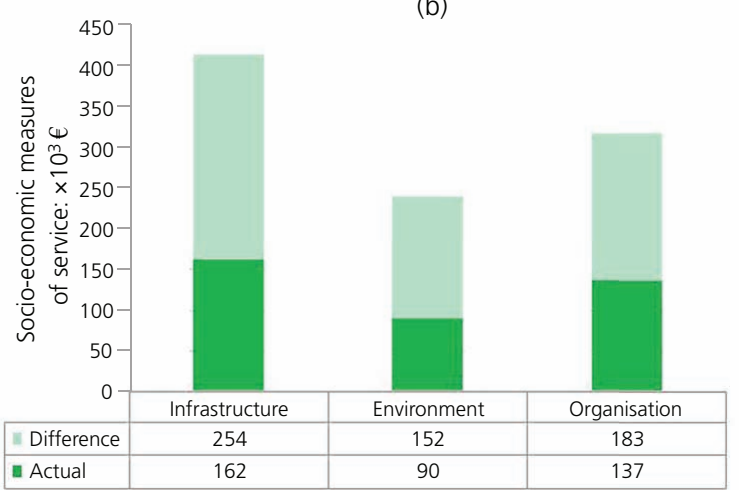

(d)

Figure 9. Difference between measures of resilience for the infrastructure, environment and organisation categories using only (a) intervention costs, (b) the travel time measure of service, (c) the safety measure of service and (d) the socio-economic measure of service

With the goal of improving resilience - that is, decreasing the measure of resilience for the transport system - the infrastructure manager should focus his attention in improving the values of the aforementioned indicators. It should be kept in mind from the beginning on, though, that some of these are relatively easy to modify - that is, the expected condition of infrastructure (1.3.5), currently $1 / 3$; the condition of the protection barriers (1.3.3), currently $2 / 5$; and the extent of interventions executed prior to the landslide (3.1.3), currently $1 / 2$ - and another that is impossible to modify - that is, the hazard zone of the infrastructure (2.1.5). Once clarity is achieved on the measures of resilience, the infrastructure manager can proceed to setting targets on the values of the indicators taking into consideration the ease with which values can be improved.

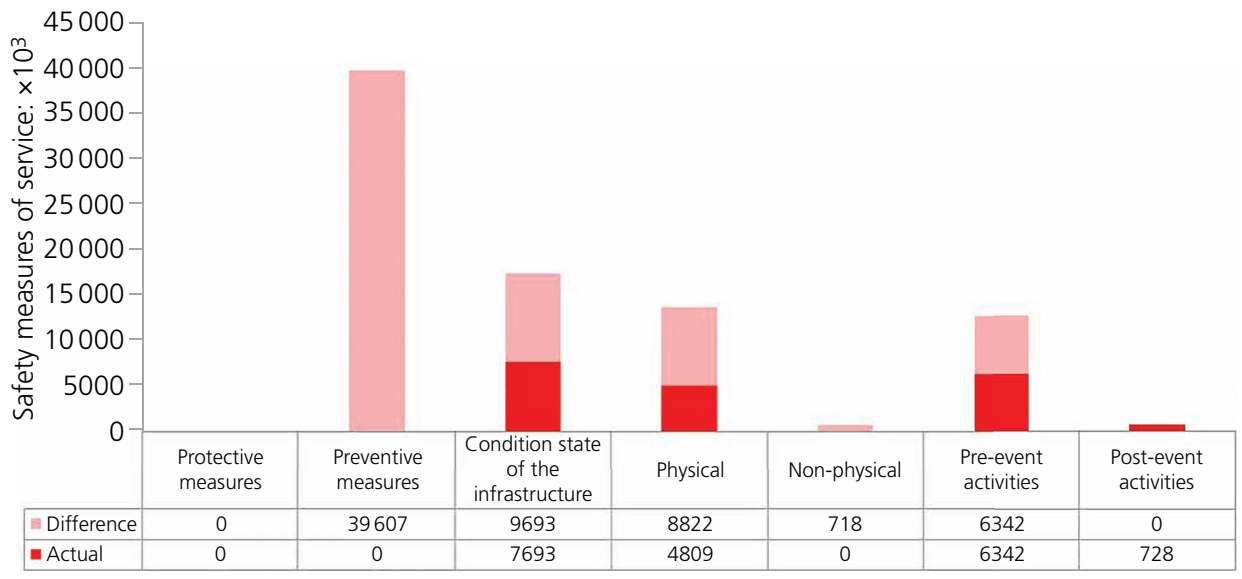

Figure 10. Difference between measures of resilience for the indicator categories condition state, protection measures, preventive measures, physical and non-physical environment and pre- and post-event activities 


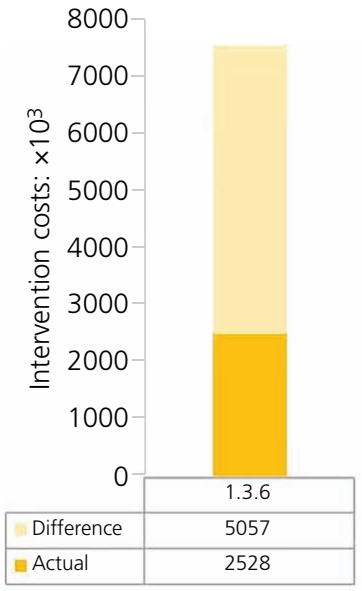

(a)

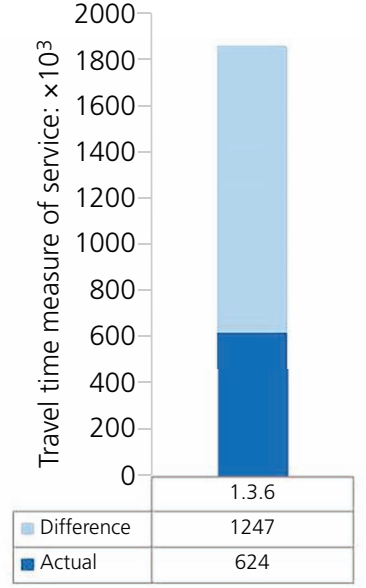

(b)

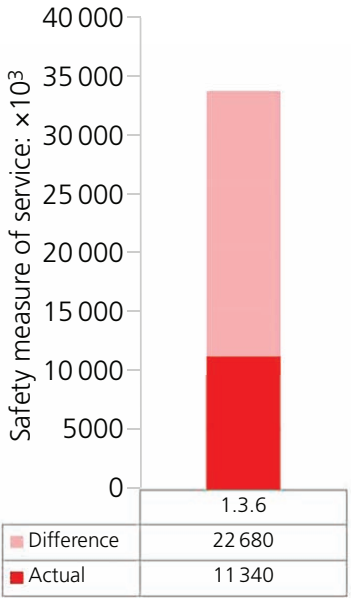

(c)

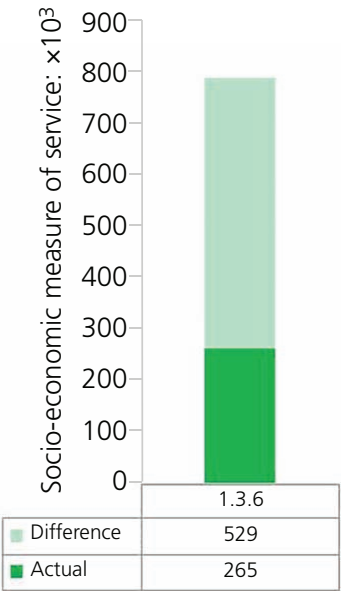

(d)

Figure 11. Difference between measures of resilience for the indicator expected condition state of protective barriers (1.3.6): (a) intervention costs; (b) travel time measure of service; (c) safety measure of service and (d) socio-economic measure of service

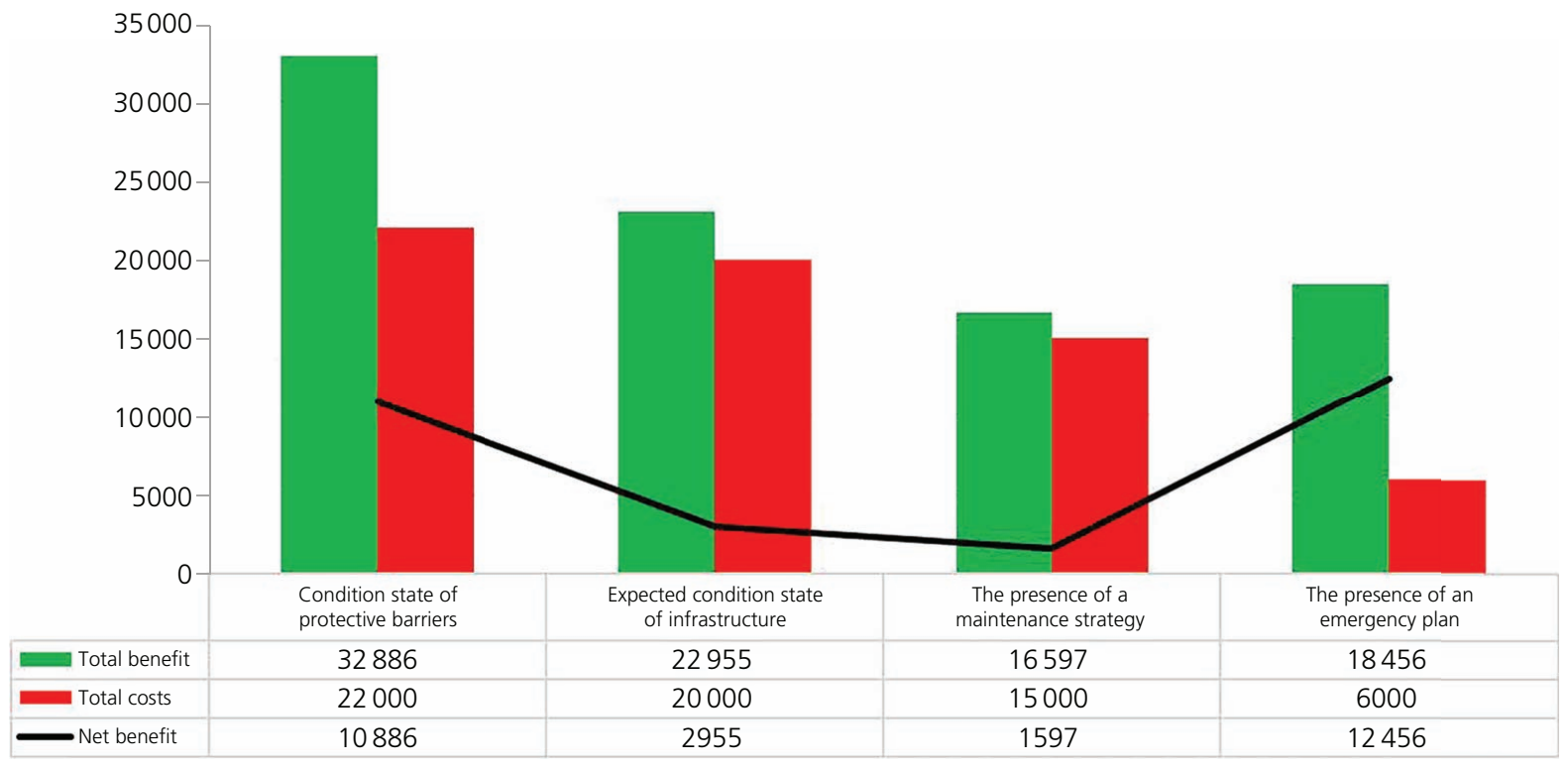

Figure 12. Total benefit, total costs and net benefit to align the current four indicators out of target to their targets

\section{Targets}

The resilience indicator targets for the example infrastructure were set for the indicators that were considered to be in the control of the infrastructure manager (31 out of the 42 ). In general, the infrastructure manager should first identify both the legal requirements and his own, as well as the owners' requirements that is, the things that they empirically know had to be done. He then systematically estimated the approximate costs and benefits of improving the values of each of the indicators, with respect to the likely restoration costs and the likely reductions in service with respect to the reference landslide. Finally, he then selected the target values that were likely to give the maximum net benefit while satisfying all of the requirements. Each of these steps is explained in the following sections in more detail, although in this example, it was considered that no requirements - that is, neither legal nor stakeholders' requirements - bounded the decision. Thus, the process to set the targets starts directly with the estimate of the net benefit.

\section{Net benefit}

Beyond the requirements for the indicator values, the targets were determined using incremental cost-benefit analysis - that is, for each indicator estimating the approximate net benefit from the lowest acceptable level to the level where the incremental net benefit of a further increase is negative (which is equivalent to the benefit/cost ratio (B/C) being less than 1.0). An example of how 
Table 13. Setting targets based on net benefit for the condition state of the protective barriers

\begin{tabular}{|c|c|c|c|c|c|c|c|c|c|c|}
\hline \multirow{3}{*}{$\begin{array}{l}\text { Possible } \\
\text { value }\end{array}$} & \multirow{3}{*}{$\begin{array}{l}\text { Costs: } \\
\times 10^{3} €\end{array}$} & \multirow{3}{*}{ Target } & \multirow{3}{*}{$\begin{array}{l}\text { Max per } \\
\text { value }\end{array}$} & \multicolumn{6}{|c|}{ Measures of resilience: $\times 10^{3} €$} & \multirow{3}{*}{$\begin{array}{l}\text { Net benefit: } \\
\times 10^{3} €\end{array}$} \\
\hline & & & & \multirow{2}{*}{$\begin{array}{l}\text { Avoided intervention } \\
\text { costs }\end{array}$} & \multicolumn{4}{|c|}{ Avoided reductions in service } & \multirow[b]{2}{*}{$\mathrm{B} / \mathrm{C}$} & \\
\hline & & & & & $\begin{array}{l}\text { Travel } \\
\text { time }\end{array}$ & Safety & $\begin{array}{l}\text { Socio- } \\
\text { econ. }\end{array}$ & Total & & \\
\hline & & & Max & 9391 & 2317 & 42120 & 983 & 54811 & N/A & N/A \\
\hline 0 & 0 & & 0 & 0 & 0 & 0 & 0 & 0 & 0.00 & 0 \\
\hline 1 & 3000 & & 1 & 1878 & 463 & 8424 & 197 & 10962 & 3.65 & 7962 \\
\hline 2 & 5000 & 5 & 2 & 1878 & 463 & 8424 & 197 & 10962 & 2.19 & 5962 \\
\hline 3 & 5000 & & 3 & 1878 & 463 & 8424 & 197 & 10962 & 2.19 & 5962 \\
\hline 4 & 7000 & & 4 & 1878 & 463 & 8424 & 197 & 10962 & 1.57 & 3962 \\
\hline 5 & 10000 & & 5 & 1878 & 463 & 8424 & 197 & 10962 & 1.10 & 962 \\
\hline
\end{tabular}

In italic is marked the Max impact on the intervention costs and services, from which all the benefits (in the following rows) are derived NA, not available

this was done using the condition of the protective barriers is shown in Table 13, where the following were applied.

- The indicator was first assumed to have its worst possible value $(0)$ and the likely intervention costs and reductions in service ( $€ 54.8$ million) that would follow the occurrence of the reference landslide were estimated (listed as the maximum values for the intervention costs (€9.4 million) and the reductions in service ( $€ 2.3$ million - travel time; $€ 42$ million safety; and $€ 1$ million - socio-economic)).

- The cost of improving the value of the indicator by one unit and the expected benefit in terms of avoided intervention costs, and reductions in service, were then estimated, incrementally, assuming that the indicator had values of 1,2, 3, 4 and 5. For example, the cost of moving the value of the condition of the protective barriers indicator from 1 to 2 was estimated in $€ 5$ million and the expected avoided intervention costs and reductions in service in $€ 11$ million, yielding a net benefit of $€ 14$ million and a B/C of 2.19 , which indicated that the target should be moved to 2 from 1 . The costs of improvement of the value of this indicator were assumed to increase non-linearly, while the reductions in service were assumed to increase linearly.

- The target for the indicator was selected as the last value before the incremental net benefit became negative or the highest value possible, which in this case was 5 , and 5 was above the legal requirement of 2 .

Following this logic, targets were set for 31 resilience indicators out of the 42 presented in Tables $6-8-$ that is, 11 of the 42 indicators of the transport system have no targets. This is because they refer to situations that cannot be modified by the infrastructure manager (e.g. hazard zone), and therefore, no target can be set on these. The targets for all 31 indicators are given in Table 14.

In Table 14, it can be seen that only four indicators have actual values below the target values - that is, the condition state of protective barriers indicator (1.3.3), the expected condition state of infrastructure indicator (1.3.5), the presence of a maintenance strategy indicator (3.1.2) and the presence of an emergency plan indicator (3.2.1). Of these four indicators (Figure 12), it seems that the greatest net benefit ( $€ 12.5$ million) would be developing and improving the operative emergency plan - that is, replacing the current generic emergency plan with one where specific tasks, resources and responsibilities are defined. The second best would be improving the condition state of the protective barriers ( $€ 10.9$ million) - that is, replacing the deteriorated nets and piles. The third would be achieved by improving the expected condition of the infrastructure following the occurrence of the reference landslide event ( $€ 3$ million) - that is, reinforcing the pillars and girders of the bridges that are currently expected to have significant damage when affected by the reference landslide (e.g. as the bridge that was moved away by the landslide of 7 March 2005).The fourth would be improving the maintenance strategy ( $€ 1.6$ million) to ensure solid preventive maintenance throughout the whole infrastructure. This means that if only one thing can be done, developing an operative emergency plan should be prioritised, requiring $€ 6$ million. If all are to be done, approximately $€ 63$ million will be required.

\section{Summary}

The targets have been set for 31 out of the 42 resilience indicators, while for the 11 indicators that the infrastructure manager has no power to modify, no target has been set. Out of the 31 targets set, only four indicators currently have a value that is below the target value: the condition state of protective barriers indicator, the expected condition state of infrastructure indicator, the presence of a maintenance strategy indicator and the presence of an emergency plan indicator. Moving these indicators from their current values to the targets is expected to provide a relatively large total benefit (indicated here to be on the order of $€ 91$ million) and is expected to cost on the order of $€ 63$ million. Although more exact numbers would require more detailed analysis, these give a good idea that it is worthwhile to undertake the efforts - that is, reinforce the bridges that are currently expected to have significant damages when affected by the reference landslide, replace the deteriorated protection barriers, develop maintenance strategies for all assets on the highway and develop an operative emergency plan to be followed in the case of a landslide. 
Table 14. Targets proposed for the 31 resilience indicators considered to be in the control of the infrastructure manager

\begin{tabular}{|c|c|c|c|c|c|c|c|c|}
\hline ID & Indicator & Scale & $\begin{array}{l}\text { Actual } \\
\text { value }\end{array}$ & $\begin{array}{l}\text { Target } \\
\text { value }\end{array}$ & $\begin{array}{l}\text { Costs to reach } \\
\text { target: } \times 10^{3} €\end{array}$ & $\begin{array}{l}\text { Benefit of } \\
\text { reaching target: } \\
\times 10^{3} €\end{array}$ & $\mathrm{~B} / \mathrm{C}$ & $\begin{array}{l}\text { Net benefit of } \\
\text { reaching: } \times 10^{3} €\end{array}$ \\
\hline 1.1.1 & $\begin{array}{l}\text { The possibility of building a temporary } \\
\text { alternative route for vehicles }\end{array}$ & 2 & 0 & 0 & 0 & 0 & 0.00 & 0 \\
\hline 1.1 .2 & $\begin{array}{l}\text { The possibility of using another means } \\
\text { to satisfy the transport demand }\end{array}$ & 2 & 1 & 1 & 1200 & 1481 & 1.23 & 281 \\
\hline 1.1 .3 & $\begin{array}{l}\text { The number of possible existing } \\
\text { alternative ways to deviate vehicles }\end{array}$ & 1 & 1 & 0 & 0 & 0 & 0.00 & 0 \\
\hline 1.1 .4 & The presence of a warning system & 2 & 2 & 2 & 2500 & 3046 & 1.02 & 546 \\
\hline 1.1 .5 & The presence of a safe shutdown system & 1 & 0 & 0 & 0 & 0 & 0.00 & 0 \\
\hline 1.1 .6 & $\begin{array}{l}\text { The presence of emergency/evacuation } \\
\text { paths }\end{array}$ & 2 & 1 & 1 & 0 & 0 & 0.00 & 0 \\
\hline 1.1.7 & $\begin{array}{l}\text { The presence of special measures to } \\
\text { help evacuate persons }\end{array}$ & 2 & 0 & 0 & 0 & 0 & 0.00 & 0 \\
\hline 1.2 .1 & $\begin{array}{l}\text { Compliance with the current slope } \\
\text { stability design code }\end{array}$ & 2 & 2 & 1 & 0 & 0 & 0.00 & 0 \\
\hline 1.2 .2 & Presence of protection barriers & 1 & 1 & 0 & 0 & 0 & 0.00 & 0 \\
\hline 1.2 .3 & Adequate protection barriers & 1 & 1 & 1 & 2000 & 43567 & 21.78 & 41567 \\
\hline 1.3 .1 & $\begin{array}{l}\text { Age/age of replacement of the } \\
\text { warning system }\end{array}$ & 3 & 2 & 0 & 0 & 0 & 0.00 & 0 \\
\hline 1.3 .2 & Condition of infrastructure & 5 & 4 & 3 & 0 & 0 & 0.00 & 0 \\
\hline 1.3 .3 & Condition of protective barriers & 5 & 2 & 5 & 30000 & 54811 & 1.10 & 24811 \\
\hline 1.3 .4 & Condition of assistance alert systems & 5 & 2 & 1 & 2500 & 2557 & 1.02 & 57 \\
\hline 1.3 .5 & Expected condition of infrastructure & 3 & 1 & 2 & 35000 & 45910 & 1.15 & 10910 \\
\hline 1.3 .6 & Expected condition of protective barriers & 3 & 2 & 0 & 0 & 0 & 0.00 & 0 \\
\hline 1.3 .7 & $\begin{array}{l}\text { Expected condition of assistance alert } \\
\text { systems }\end{array}$ & 2 & 2 & 0 & 0 & 0 & 0.00 & 0 \\
\hline 2.1 .12 & Extent of vegetation cover & 3 & 1 & 0 & 0 & 0 & 0.00 & 0 \\
\hline 2.1 .13 & Traffic & 3 & 2 & 0 & 0 & 0 & 0.00 & 0 \\
\hline 2.1 .14 & Hazards goods traffic & 2 & 1 & 0 & 0 & 0 & 0.00 & 0 \\
\hline 2.1 .15 & Flammable goods traffic & 1 & 1 & 0 & 0 & 0 & 0.00 & 0 \\
\hline 2.2 .1 & Budget availability & 2 & 2 & 1 & 20000 & 20027 & 1.00 & 27 \\
\hline 3.1 .1 & The presence of a monitoring strategy & 2 & 1 & 0 & 0 & 0 & 0.00 & 0 \\
\hline 3.1 .2 & $\begin{array}{l}\text { The presence of an maintenance } \\
\text { strategy }\end{array}$ & 2 & 1 & 2 & 25000 & 33193 & 1.11 & 8193 \\
\hline 3.1 .3 & $\begin{array}{l}\text { The extent of interventions executed } \\
\text { prior to the event }\end{array}$ & 2 & 1 & 1 & 20000 & 28287 & 1.41 & 8287 \\
\hline 3.2 .1 & The presence of an emergency plan & 2 & 1 & 2 & 9000 & 36912 & 3.08 & 27912 \\
\hline 3.2 .2 & Practice of the emergency plan & 4 & 2 & 1 & 3000 & 3021 & 1.01 & 21 \\
\hline 3.2 .3 & Review/update of the emergency plan & 2 & 1 & 1 & 5000 & 9268 & 1.85 & 4268 \\
\hline 3.2 .4 & Expected time for tendering & 3 & 2 & 2 & 14000 & 23175 & 1.05 & 9175 \\
\hline 3.2 .5 & Expected time for demolition & 3 & 3 & 3 & 520 & 2929 & 4.58 & 3773 \\
\hline 3.2 .6 & Expected time for construction & 3 & 2 & 1 & 10000 & 14177 & 1.42 & 4177 \\
\hline
\end{tabular}

Bold was used to mark the target column, i.e. the most important point of the table, then the bold+ltalic to mark the "actual values" that are lower than the targets

\section{Conclusion}

In this paper, it is shown that the Foresee guidelines (Adey et al., 2021) provide a systematic way for infrastructure managers to obtain an idea of the resilience of their transport systems and an idea of how to set resilience targets, when infrastructure managers want to assess resilience but do not yet know where to concentrate their efforts. It is also shown that for some resilienceenhancing actions, these initial results are perhaps sufficient to take action, whereas others point to where more investigation is required, which is part of the iterative process that all infrastructure managers should be following in risk assessment (Adey et al., 2016).
The use of the guideline helps ensure that infrastructure managers define service and resilience clearly and consistently and that they are systematically considered when evaluating the resilience of the transport system, as well as obtaining an idea of how to improve resilience. The example shows that this is possible, with relatively little input and effort. Of course, if the results of such an analysis are not sufficient to plan risk-reducing interventions, they can also be used to focus on more detailed future analysis.

Future work should be focused on developing more examples with different types of infrastructure, different types of hazards and different organisations. This work could lead to organisations 
to develop more specific guidelines as to how they would like to measure service and resilience to enable them to make the best decisions possible. It may also lead to the development of country- or region-specific guidelines that would allow the fair comparison of the resilience of multiple transport systems, which would aid in the efficient distribution of limited resources. Additionally, future work should focus on investigating the accuracy of using resilience indicators when compared with results that come from detailed analysis. It is anticipated that in the framework of the Foresee project, simulations using real data will be run to demonstrate the applicability of the guidelines.

\section{Disclaimer}

The work presented in this paper is a mere exercise, for which the vast majority of inputs have been set based on authors' assumptions - that is, the inputs are realistic but fictive and as such do not reflect the current situation of the highway chosen for the present application. Therefore, the results cannot be in any way connected to the actual resilience of the real transport infrastructure. For a real assessment of the resilience of the infrastructure, the current inputs should be replaced with the actual data on the highway and relevant indicators considered. It is expected to conduct such simulation in the framework of the Foresee project to demonstrate the applicability of the guidelines.

\section{Acknowledgements}

This work has received funding from the EU Horizon 2020 research and innovation programme under grant agreement number 769373 (Foresee project). This paper reflects only the authors' views. The European Commission and Innovation and Networks Executive Agency are not responsible for any use that may be made of the information contained therein.

\section{REFERENCES}

Adey BT, Hackl J, Lam JC et al. (2016) Ensuring acceptable levels of infrastructure related risks due to natural hazards with emphasis on stress tests. Proceedings of the 1st International Symposium on Infrastructure Asset Management (SIAM), Kyoto, Japan.

Adey BT, Martani C, Kielhauser C et al. (2021) Estimating, and setting targets for, the resilience of transport infrastructure. Infrastructure Asset Management, in press.

Wikipedia (2021) Autostrada A16 (Italia). Wikimedia Foundation, Inc., San Francisco, CA, USA (in Italian). See https://it.wikipedia.org/wiki/ Autostrada_A16_(Italia) (accessed 16/03/2021).

\section{How can you contribute?}

To discuss this paper, please submit up to 500 words to the editor at journals@ice.org.uk. Your contribution will be forwarded to the author(s) for a reply and, if considered appropriate by the editorial board, it will be published as a discussion in a future issue of the journal. 